\title{
Diversity patterns of marine heterotrophic culturable bacteria along vertical and latitudinal gradients
}

\author{
Isabel Sanz-Sáeza, Guillem Salazarb, Elena Laraa, c, Marta Royo-Lloncha, Dolors \\ Vaquéa, Carlos M. Duarted, e, Josep M. Gasola, Carlos Pedrós-Alióf, Olga Sánchezg *, \\ Silvia G. Acinasa*
}

a Departament de Biologia Marina i Oceanografia, Institut de Ciències del Mar, ICMCSIC, Barcelona, Catalunya, Spain

b Department of Biology, Institute of Microbiology, ETH Zurich, Vladimir-Prelog-Weg 1-5/10, CH-8093 Zurich, Switzerland.

c Institute of Marine Sciences (CNR-ISMAR), National Research Council, Castello 2737/F Arsenale-Tesa 104, 30122 Venezia, Italy

d Red Sea Research Center, King Abdullah University of Science and Technology (KAUST), Thuwal 23955-6900, Saudi Arabia.

e Computational Bioscience Research Center (CBRC), King Abdullah University of Science and Technology (KAUST), Thuwal 23955-6900, Saudi Arabia

f Department of Systems Biology, Centro Nacional de Biotecnología (CNB), CSIC, Madrid, Spain

g Departament de Genètica i Microbiologia, Facultat de Biociències, Universitat Autònoma de Barcelona, 08193 Bellaterra, Spain

*Correspondence: Olga Sánchez: olga.sanchez@uab.es, tel. (+34) 93586 8022, FAX (+34) 93581 2387; Silvia G. Acinas: sacinas@icm.csic.es, tel. (+34) 93230 5886, FAX (+34) 932309555 


\begin{abstract}
Nowadays, there is a significant gap in the knowledge of the diversity and patterns for marine heterotrophic culturable microorganisms. In addition, most of the bacterial isolation efforts have focused on the photic ocean leaving the deep ocean less explored. We have isolated 1561 bacterial strains covering both photic (817) and aphotic layers (744) including isolates from the oxygen minimum zone (362) and the bathypelagic (382) from a variety of oceanographic regions including the North Western Mediterranean Sea, the North and South Atlantic Oceans, the Indian, the Pacific, and the Arctic Oceans. The partial sequencing of the $16 \mathrm{~S}$ rRNA gene of all isolates revealed that they mainly affiliate with the classes Alphaproteobacteria (35.9\%) and Gammaproteobacteria (38.6\%), as well as, phylum Bacteroidetes (16.5\%). The genera Alteromonas and Erythrobacter were the most widespread heterotrophic bacteria in the ocean able to grow on solid agar media. When comparing the sequences of all isolates, $37 \%$ of them were $100 \%$ identical. In fact, we found that $59 \%$ of the total aphotic isolates were $100 \%$ identical to photic isolates, indicating the ubiquity of some bacterial isolates along the water column. Unweighted UniFrac distances did not show significant differences among stations regardless of their geographic distance or depth, reflecting the wide dispersion of the culturable bacterial assemblage. This isolates collection provides an overview of the distribution patterns of cosmopolitan marine culturable heterotrophic bacteria.
\end{abstract}

Keywords: bacterial isolates, deep ocean, photic ocean, diversity patterns. 


\section{Introduction}

High-throughput sequencing (HTS) studies of ribosomal genes [1] have provided great advances in the knowledge of microbial diversity in multiple environments including marine ecosystems [2-4]. They allowed to study the richness and community composition of marine bacterioplankton communities, as well as, the identification and functional insights of the most abundant microorganisms [5-7]. Different main patterns emerged from 16S rRNA amplicon tags (16S iTAGs) and metagenomic (16S miTAGs) studies applied to ocean ecosystems: (i) the presence of few abundant operational taxonomic units (OTUs) and a long tail of rare and low abundant OTUs, called the "rare biosphere" [1, 8, 9], (ii) an increase of richness in deeper layers [3, 10], (iii) the vertical segregation between photic and aphotic samples [3] but also vertical connectivity between surface and deep ocean taxa through sinking particles [11], (iv) the limited dispersion of bacterial communities across space $[3,12,13]$ and, (v) the presence of few cosmopolitan taxa $[14,15]$. However, there is still a significant gap in the knowledge of the diversity of culturable microorganisms in the ocean, and if similar patterns are applied to this fraction of the bacterioplankton community, specifically covering broader gradients. Also, it is unclear which are the most cosmopolitan culturable marine heterotrophic bacteria in the ocean.

On top of that, most of the studies targeting the marine heterotrophic culturable bacteria have focused on the upper ocean (0-200 m depth) or on specific oceanographic regions [16-19], while studies covering vertical gradients are less frequent [20-22]. Efforts to culture bacteria from the deep ocean $(>200 \mathrm{~m}$ ) have focused mostly on isolates from hydrothermal vents [23-25], whale carcasses [26], trenches [27], and deep-sea sediments [22, 28-31]. Thus, very few studies have analyzed the diversity of isolates from mesopelagic (in particular the oxygen minimum zone (OMZ) [32-34]), the bathypelagic and abyssopelagic waters [20, 35-37], and those available were mainly done at a local or regional scale. Thus, a study of the culturable microorganisms covering vertical gradients including underexplored areas such as the $\mathrm{OMZ}$ and the bathypelagic areas is missing.

Here we present an extensive marine heterotrophic bacterial culture collection with 1561 marine bacteria retrieved from different seawater depths covering also a large geographical extent and latitude. Through the analysis of their partial 16S rRNA sequences (average $526 \mathrm{bp}$ ), we aim to describe some general patters of isolated bacteria rather than describe new bacterial species. To do that we used a well stablished 
marine solid medium in order to describe that fraction of the bacterioplankton community than can be commonly isolated under laboratory conditions (nutrient rich medium, standard oxygen concentrations and atmospheric pressure). We have revealed both the most cosmopolitan and the locally distributed heterotrophic culturable bacteria across oceans, and revealed some different patterns of vertical distribution showing large connectivity and dispersion of the isolated heterotrophic fraction.

\section{Materials and methods}

\section{Study areas and sampling}

A total of eight photic-layer, four OMZ, and seven bathypelagic samples were taken during different oceanographic cruises in several sampling stations distributed along a wide range of latitudes (Fig. 1). Photic layer samples (Table 1) were collected in the Atlantic and Indian Oceans during the Tara Oceans expedition in 2009-2013 [38], and from the Arctic Ocean during the ATP 09 cruise in 2009 [39]. Additionally, surface seawater samples from the Blanes Bay Microbial Observatory (BBMO, http://www.icm.csic.es/bio/projects/icmicrobis/bbmo) in the NW Mediterranean Sea were collected in May 2015. Oxygen minimum zone samples (Table 1) were taken from the Indian and Pacific Oceans also during the Tara Oceans expedition in 2009-2013 [38]. Bathypelagic samples (Table 1) from the Atlantic Ocean at $~ 4000 \mathrm{~m}$ depth were taken from six different stations during the Malaspina 2010 Circumnavigation Expedition [40]. One of the stations sampled was located in the North Atlantic Ocean, whereas the other five stations were located in the South Atlantic Ocean; one of them was particularly placed in the Agulhas Ring, where deep waters from the South Atlantic converge and mix with Indian Ocean deep-water masses [41]. In addition, one bathypelagic sample was collected at $2000 \mathrm{~m}$ depth in the NW Mediterranean during the MIFASOL cruise in September 2014.

In each of these stations, seawater was collected using Niskin bottles attached to a rosette sampling system, except at BBMO, where samples were collected with a bucket. Seawater was sequentially filtered through $200 \mu \mathrm{m}$ and $20 \mu \mathrm{m}$ meshes to remove large plankton cells. Two subsamples were kept in $2 \mathrm{ml}$ Eppendorf tubes with DMSO 7\% final concentration and stored at $-80^{\circ} \mathrm{C}$ until further processing in the laboratory.

Geographical coordinates of stations, sampled depth, in situ temperature and total number of sequenced isolates are listed in Table 1. 


\section{Culturing and isolation}

Isolates were obtained by plating $100 \mu$ of undiluted and 10x diluted seawater from the photic, OMZ and bathypelagic samples, in triplicates, onto Zobell agar plates (i.e. $5 \mathrm{~g}$ peptone, $1 \mathrm{~g}$ yeast extract and $15 \mathrm{~g}$ agar in $750 \mathrm{ml}$ of $30 \mathrm{kDa}$ filtered seawater and 250 $\mathrm{ml}$ of Milli-Q water) or Marine Agar 2216 plates, which is based also on the Zobell medium formulation [42] (5 g peptone, $1 \mathrm{~g}$ yeast extract, $0.1 \mathrm{~g}$ ferric citrate, $19.4 \mathrm{~g}$ sodium chloride, $8.8 \mathrm{~g}$ magnesium chloride, $3.24 \mathrm{~g}$ sodium sulphate, $1.8 \mathrm{~g}$ calcium chloride, 0.5 $\mathrm{g}$ potassium chloride, $0.16 \mathrm{~g}$ sodium bicarbonate, $0.08 \mathrm{~g}$ potassium bromide, $0.034 \mathrm{~g}$ strontium chloride, $0.022 \mathrm{~g}$ boric acid, $0.004 \mathrm{~g}$ sodium silicate, $0.0016 \mathrm{~g}$ ammonium nitrate, $0.008 \mathrm{~g}$ disodium phosphate, $0.0024 \mathrm{~g}$ sodium fluorate, $15 \mathrm{~g}$ agar in $1 \mathrm{~L}$ of distilled water). Our medium culturing strategy was only focused to retrieve heterotrophic marine bacteria that could grow easily under laboratory conditions (nutrient rich media, standard oxygen concentrations and atmospheric pressure) using two similar culturing media. The only difference between Zobell agar and Marine Agar 2216 plates is the use of natural seawater (Zobell agar), or the addition of the minerals and salts contained in natural seawater to distilled water (Marine Agar 2216). Indeed, we did not observe significant differences (Fisher test analyses, data not shown) in the bacterial isolation between both media.

Photic layer and OMZ samples were incubated at room temperature (RT), while bathypelagic samples were incubated at their in situ temperature, which ranged from $\sim 4^{\circ} \mathrm{C}$ in the (Atlantic Ocean at $4000 \mathrm{~m}$ depth) to $12^{\circ} \mathrm{C}$ (NW Mediterranean at $2000 \mathrm{~m}$ depth) (Tables 1 and $\mathrm{S} 1$ ), but also at RT in order to assure bacterial recovery from all stations. In all cases, triplicates of each temperature condition and dilution were incubated in the dark until no more colonies appeared (10-30 days).

A total of 1561 bacterial isolates were randomly selected for DNA amplification and partial sequencing of their 16S rRNA gene (Table 1 and details below). Similar number of isolates were sequenced from photic layers (817; average: 102 isolates per station) and from deep oceans (744; average: 67 isolates per station) with 362 isolates from the $\mathrm{OMZ}$ and 382 from the bathypelagic. In most of the bathypelagic samples we collected all colonies appearing in the plates, which ranged from 6 to 129. Colonies were streaked on agar plates in duplicate to ensure their purity and avoid contamination. The isolates were stored in the broth medium used with glycerol $25 \%$ in cryovials at $-80^{\circ} \mathrm{C}$. 


\section{PCR amplification and sequencing of the 16S rRNA gene}

Available DNA used for template in Polymerase Chain Reaction (PCR) was extracted from $200 \mu \mathrm{L}$ of isolates liquid cultures placed in 96 well plates, diluted 1:4 and heated $\left(95^{\circ} \mathrm{C}, 15 \mathrm{~min}\right)$ to cause cell lyses. The partial 16S rRNA gene sequences were PCR amplified using bacterial primers 358F (5'-CCT ACG GGA GGC AGC AG-3') [43] and 907Rmod (5'-CCG TCA ATT CMT TTG AGT TT-3') [44]. The complete 16S rRNA gene was amplified in specific strains after DNA extraction using the DNeasy Blood \& Tissue kit (Qiagen), following the manufacturer's recommendations, and using the modified primers from Page et al. [45] 27F (5'- AGR GTT TGA TCM TGG CTC AG -3') and 1492R (5'- TAC GGY TAC CTT GTT AYG ACT T -3'). Each PCR reaction with a final volume of $25 \mu$ contained: $2 \mu$ l of template DNA, $0.5 \mu$ of each deoxynucleotide triphosphate at a concentration of $10 \mu \mathrm{M}, 0.75 \mu \mathrm{l}$ of $\mathrm{MgCl}_{2} 1.5 \mathrm{mM}, 0.5 \mu$ of each primer at a concentration of $10 \mu \mathrm{M}, 0.125 \mu$ of Taq DNA polymerase (Invitrogen), $2.5 \mu$ of PCR buffer supplied by the manufacturer (Invitrogen, Paisley, UK) and Milli-Q water up to the final volume. Reactions were carried out in a Biorad thermocycler using the following program: initial denaturation at $94^{\circ} \mathrm{C}$ for $5 \mathrm{~min}$, followed by 30 cycles of $1 \mathrm{~min}$ at $94^{\circ} \mathrm{C}, 1 \mathrm{~min}$ at $55^{\circ} \mathrm{C}$ and $2 \mathrm{~min}$ at $72^{\circ} \mathrm{C}$, and a final extension step of $10 \mathrm{~min}$ at $72^{\circ} \mathrm{C}$. The PCR products were verified and quantified by agarose gel electrophoresis with a standard low DNA mass ladder (Invitrogen). Purification and OneShot Sanger sequencing of 16S rRNA gene products was performed by Genoscreen (Lille, France) with primer 358F for partial sequences, and with both $27 \mathrm{~F}$ and 1492R for complete sequences. ChromasPro 2.1.8 software (Technelysium) was used for manual cleaning and quality control of the sequences.

\section{Data processing and taxonomic classification}

The 16S rRNA sequences of our cultured strains were clustered at $99 \%$ sequence similarity [46] in order to define different operational taxonomic units (OTUs or isolated OTUs) and construct OTU-abundance tables for the different stations and layers studied (Table S2) using UCLUST algorithm from the USEARCH software [47]. The different OTUs were taxonomically classified using the least common ancestor (LCA) method in SINA classifier [48], using both Silva (release 132 in 2017) and RDP (Ribosomal Database Project, release 11) databases. Parallelly, isolates sequences were submitted to BLASTn [49] with two subsets of the RDP database. One including only the uncultured bacteria (Closest Environmental Match, CEM), and another including only the cultured bacteria (Closest Cultured Match, CCM) in order to extract the percentages of similarity 
with both datasets (Table S3 and Table S4), and to assess whether our isolates were similar to effectively published cultured organisms.

Additionally, a more restrictive clustering at $100 \%$ sequence similarity (USEARCH software) was used to define OTUs and to detect how many bathypelagic, OMZ and photic-layer bacterial isolates were identical, and thus, to identify bacterial taxa or strains that could distribute along all the water column. Such comparisons were done with: (i) photic and bathypelagic isolates sequences retrieved from neighbouring stations and (ii) the whole isolates dataset.

\section{Comparisons between layers and statistical analyses}

To infer differences between the diversity and richness of the isolates obtained along the oceanic vertical gradient, the OTU-abundance table constructed with the sequences clustering at $99 \%$ was sampled down to the lowest sampling effort (362 isolates in the $\mathrm{OMZ}$ ). In this manner, the rarefied or subsampled OTU table was obtained using the function rrarefy.perm with 1000 permutations from the R package EcolUtils [50], while rarefaction curves to estimate the sampling effort were performed with the package vegan 2.5-3 [51]. Calculation of Chao1 and ACE species richness estimates, and Shannon-Weaver and Simpson diversity index estimates were also carried out with the rarefied OTU table using the $\mathrm{R}$ package vegan version $2.5-3$.

The coverage $(C)$ for each of the depths was also calculated by the equation $C=$ $\left[1-\left(\frac{n_{1}}{N}\right)\right] * 100 \%$, where $N$ is the number of OTUs being examined and $n_{1}$ represents the number of OTUs occurring only once or singletons [52].

Fisher tests were performed in R package stats version 3.4.3 [53] and were used to: (i) detect taxa with a significant presence at a specific depth in those truly comparable stations, that is stations which present photic and bathypelagic samples from neighbouring stations, and (ii) evaluate this significant presence of certain taxa in a specific layer including all photic, $\mathrm{OMZ}$ and bathypelagic samples. $P$-values of the Fisher test were adjusted for multiple comparisons using the Hochberg False Discovery Rate correction (FDR). To assess significance, the statistical analyses were set to a conservative alpha value of 0.01 . 


\section{Phylogenetic analysis}

In order to see phylogenetic relationships and explore the connectivity between photiclayer, OMZ and bathypelagic isolates, as well as, to detect possible novel strains, phylogenetic trees for Alphaproteobacteria, Gammaproteobacteria, Bacteroidetes and Gram positive bacteria (Fig. S1a-d) were built. They included the non-redundant sequences dataset of each station and the taxonomic affiliation of their Closest Cultured Match (CCM) and Closest Environmental Match (CEM) obtained after BLASTn search against the RDP databases (Table S3 and S4). The total pool of sequences were first aligned with the SINA web alignment tool (http://www.arb-silva.de/aligner/) [48] and imported into the phylogenetic software MEGA 5.2.2 [54]. The phylogenetic trees were constructed with the Neighbour Joining (NJ) algorithm using the Jukes-Cantor distance and 1000 bootstrap replicates.

Additionally, to support the novelty of putative new species or genera (isolates that presented a percentage of similarity below the $97 \%$ with public databases), the complete 16S rRNA gene was sequenced for one isolate, with which two more strains clustered at $100 \%$ similarity, and phylogenetic trees were constructed as described above. The trees included the complete and partial sequences, the best hits from uncultured and cultured microorganisms, extracted from local alignments against RDP 11, Silva LTP (Living Tree project), and National Center for Biotechnology Information (NCBI) databases, and the reference 16S rRNA genes from their related genera.

\section{Analyses of the genetic distances between retrieved isolates}

Unweighted UniFrac distances between isolates of the different stations were calculated using the $R$ version 3.4.3 [53] package picante [55]. The analysis required a phylogenetic tree including all the isolates sequences, and an outgroup sequence (Rhodopirellula baltica, accession number EF012748), which was constructed as mentioned above, and an OTU-abundance table constructed at $100 \%$ sequence similarity using the UCLUST algorithm from the USEARCH software [47] indicating the presence of the different OTUs in each of the samples studied. The resulting UniFrac distance matrix was used to estimate genetic distances between samples from different depths and to perform a nonmetric multidimensional scaling analysis [56] using the R package vegan 2.5-3 [51]. Oneway analysis of variance (ANOVA) test followed by the post hoc Tukey's Honestly significant difference (HSD) test from the R package stats version 3.4.3 [53] was perform to see significative differences between groups. To asses significance, the statistical analyses were set to a conservative alpha value of 0.05 . Furthermore, we performed 
different analyses to test whether environmental parameters (temperature, salinity) and Chlorophyll a ( $\mathrm{Ch} / \mathrm{a})$ could explain the patterns of genetic distance between samples of different depths: (i) a Mantel test correlation with the R package ape version 5.1 [57], including the unweighted UniFrac distance matrix and a distance matrix based on Euclidian distances between the scaled environmental parameters, and (ii) a distancebased redundancy analysis (dbRDA, [58]) with the R package vegan version 2.5-3.

\section{Nucleotide sequences accession number}

The 16S rRNA gene sequences of the bacterial isolates retrieved in this study were deposited in GenBank. Sequences from all isolates, except those coming from the OMZ regions and those from the surface Indian Ocean, are deposited under the following accession numbers MH731309 - MH732621. Notice that among these accession numbers other isolates are included, originated from the same locations but isolated with another culture medium and not included in this study. Isolates retrieved from the OMZ and those from the surface Indian Ocean are deposited under the following accession numbers MK658870-MK659428.

\section{Results}

Bacterial richness and diversity patterns of heterotrophic isolates

The partial 16S rRNA sequences of the cultured strains were grouped into operational taxonomic units (isolated OTUs, referred hereafter as OTUs) using similarity thresholds at $99 \%$ (OTUs99) and 100\% (OTUs100). Those OTUs were then compared and analysed.

The number of OTUs detected and the observed richness (S.obs) was very similar in all layers for both OTUs 100 and OTUs99, being the OMZ the layer with the lowest observed values (Table 2). Rarefaction curves for the non-rarefied (Fig. 2a) and rarefied (Fig. 2b) OTU tables showed slightly higher richness for the photic samples compared to the OMZ and bathypelagic but they did not reach an asymptote. Thus, we calculated the species richness estimates (Chao-1, ACE) and they increased with depth for OTUs100 (from 140 in the photic up to 174 in the bathypelagic), but it was in the OMZ where we found higher values for the OTUs99 (Table 2). Nevertheless, Shannon-Weaver and Simpson diversity indices showed, for both clustering thresholds, a slightly higher diversity for photic layers. Good's coverage analyses per layer ranged from 48.8 to $55.8 \%$ (OTUs 100 ) and from 
56.1 to $70.5 \%$ (OTUs99)(Table 2). These results indicated that the isolates dataset, even if not saturated, represents a reasonable inventory of the heterotrophic marine bacteria.

Finally, rank abundance plots of the non-rarefied (Fig. 2c) and rarefied (Fig. 2d) OTU tables presented, for the three depths studied, a steep curve, which is indicative of low evenness. Thus, there were a few abundant OTUs with a large number of strains and a large proportion of OTUs that had few representatives (rare OTUs).

Shared diversity between photic and bathypelagic samples from neighbouring stations

The $38216 \mathrm{~S}$ rRNA sequences from the bathypelagic samples were compared to the 437 photic-layer sequences (excluding those from the Indian and Arctic Ocean because bathypelagic isolates could not be retrieved in these cases). The data were normalized down to the lowest isolated sequences that corresponded to the strains retrieved from the bathypelagic ocean, but very similar results were obtained with the rarefied and nonrarefied data (Table S5). Surprisingly, a large proportion (58.9\%) of the bathypelagic sequences were $100 \%$ identical to those of the photic isolates. Further analyses in both sets of sequences were done at both OTU and genus taxonomic level (Fig. 3) and showed that photic isolates clustered in 73 different OTUs while bathypelagic isolates clustered in 56 OTUs (99\% sequence similarity). Slightly higher numbers of Gammaproteobacteria, Alphaproteobacteria, and Bacteroidetes OTUs were retrieved from the photic layer (Fig. 3a). More differences were found in the Actinobacteria, dominated by only photic-layer OTUs, and Firmicutes, present only in the bathypelagic. Furthermore, when we analyzed together the photic and bathypelagic isolates and we defined OTUs at $99 \%$ sequence similarity, we found 29 OTUs which included strains of both layers (Fig. 3b). These shared OTUs included $68.9 \%$ of the sequences (Fig. 3b) and an average number of 18.2 sequences per OTU. Despite the fact that this large group of OTUs was found in both layers, 41 OTUs, representing $18.3 \%$ of the sequences, were still found only in the photic zone, with an average number of 3.4 sequences per OTU. On the other hand, 28 OTUs (12.8\% of the sequences) were found only in the bathypelagic ocean, with an average of 3.5 sequences per OTU (Fig. 3b)(Table S6). At the genus level we found 23 genera common to both layers (including $80.4 \%$ of the analysed sequences), 10 (4.6\%) only in the bathypelagic zone and 24 (15\%) among the photic isolates (Table S7). Some of the isolates that were only recovered from the bathypelagic waters belonged to Bacillus, Loktanella, Novosphingobium, or Roseovarius, whereas all the genera affiliating with the Actinobacteria phylum and other genera, including Maricaulis, Polaribacter, Roseivirga, Vibrio or Winogradskyella, were 
only isolated from the photic-layer within our dataset. Nevertheless, Fisher tests (Table S8) indicated a significative presence of Roseivirga, Winogradskyella, and Vibrio in the photic layer, while Sulfitobacter, despite being found in both layers, was more prone to be isolated from the bathypelagic samples.

Shared diversity between all photic, OMZ, and bathypelagic samples across oceans

We explored the similarity between OTUs from different layers (photic, OMZ and bathypelagic) and across distant oceans covering large spatial and latitudinal scales. The non-rarefied OTU table (OTUs99), including all the photic (817), OMZ (362), and bathypelagic (382) isolates, and the rarefied OTU table down to the lowest isolated depth (OMZ) were used for analyses, and because minor differences were observed (Table S9 and $\mathrm{S10}$ ), the results mentioned here refer only to those obtained with the rarefaction. The 122 OTUs obtained, revealed that 15 OTUs (Fig. 3c) included isolates from all layers, accounting for $52.7 \%$ of the total sequences (Fig. 3c). Further, eight OTUs $(12.7 \%$ of the sequences) were common to photic and bathypelagic isolates, nine (6.6\%) to photic and $\mathrm{OMZ}$ isolates, and eight (7.36\%) to OMZ and bathypelagic isolates (Fig. 3c). Nevertheless, a substantial proportion of isolates were only retrieved from one of the layers: 29 OTUs were only found in the photic samples, 25 in the OMZ, and 28 in the bathypelagic samples (Fig. 3c)(Table S11). The taxonomic classification of these OTUs, using the LCA method, designated a total of 59 different genera and 10 OTUs that could not be classified at the genus level. From these 59 genera, 13 genera were found along all the water column including $75 \%$ of the total isolates, and between four and six genera were shared by two layers. On the other hand, the photic ocean was again the layer with the highest number of retrieved genera that were not observed in the other two depths, even though they accounted for only $5.6 \%$ of the sequences (Table S12). Interestingly, Fisher tests applied to the genera retrieved indicated again more recovery of Roseivirga, Vibrio and Winogradskyella in the photic layers and of Sulfitobacter in the bathypelagic. Additionally, some other genera that were mostly isolated from only one of the depths within our dataset seemed to have also a significative presence in a specific layer, such as Nereida, Maricaulis (Photic), Gramella (OMZ), or Joostella (Bathypelagic) (Table S13).

\section{Cosmopolitan vs locally distribution of heterotrophic bacterial OTU isolates}

The most abundant and cosmopolitan culturable OTUs and genera, i.e. those that occurred in all or most (around $80 \%$ ) of the 19 stations studied, and the ones only retrieved locally with a restricted distribution [59] within the samples studied were 
identified. Seven OTUs were the most abundant ones with more than 50 isolates each (Fig. 4a). From these, only OTU 1, affiliating to Alteromonas sp., with 217 isolates, showed a global distribution, appearing in $80 \%$ of the stations sampled, and thus, it was truly cosmopolitan. The other six abundant OTUs, affiliating to the genera Erythrobacter, Marinobacter and Halomonas, had a regional distribution having been isolated in more than $25 \%$, but less than $75 \%$ of the samples. Moreover, we found 13 less abundant OTUs that also presented a regional distribution and covered different oceanographic regions (Table S2). The remaining OTUs, representing $86.3 \%$ of the total OTUs, were isolated locally, that is, in less than $25 \%$ of the samples.

Erythrobacter and Alteromonas were the most abundant and cosmopolitan genera, representing $41.3 \%$ of the isolates (338 and 333 isolates respectively), and appearing in $94 \%$ of the samples studied (Fig. 4b). Less abundant genera such as Marinobacter (113 isolates), Halomonas (70 isolates), Pseudoalteromonas (51 Isolates), Idiomarina (42 isolates), Pseudomonas (29 isolate), Sulfitobacter (51 Isolates), or Oceanicaulis (46 isolates) were present in more than $25 \%$ of the samples (Fig. $4 \mathrm{~b}$ ) and covered almost all the oceanographic regions (Table S14). These were, thus, regionally distributed [59]. Some genera such as Psychrobacter, Leeuwenhoekiella or Alcanivorax had lower numbers of isolates, but were recovered in more than $25 \%$ of the samples (Fig. $4 \mathrm{~b}$ ). Other genera, in turn, such as Zunongwangia, were recovered in less than $25 \%$ of the samples but presented 54 isolates (3.5\% of the sequences). All the mentioned genera were found in the photic, OMZ, and bathypelagic layers, except for Oceanicaulis which could not be retrieved from the bathypelagic samples (Table S14). Finally, the remaining genera represented $20 \%$ of the cultures and were recovered only in some of the stations.

Patterns of genetic distance among culturable heterotrophic marine bacteria

Unweighted UniFrac distances were calculated between pairs of stations and they are expressed with values ranging from $0(100 \%$ similarity) to $1(0 \%$ similarity). Distances between photic-layer stations ranged from 0.31 to 0.79 , between $\mathrm{OMZ}$ from 0.52 to 0.75 , and between bathypelagic samples from 0.48 to 0.8 (Fig. 5a). When we compared the genetic distances between different depths (Fig. 5a), we did not find higher dissimilarities than between those stations coming from the same layer. Besides, ANOVA results indicated that the differences between compared groups were not statistically significant $(P$-value $=0.08)$. Furthermore, non-metric multidimensional scaling plot (NMDS, Fig. 5b) of the UniFrac distances did not display a clear separation between samples from different layers. On the other hand, we did not find any correlation between genetic and geographical distances (Fig. 6a). In other words, we did not find higher genetic 
dissimilarities when the geographic distance between stations increased. The Mantel correlation between the genetic and the environmental matrix considering conservative properties of oceanic waters, such as temperature and salinity, or the chlorophyll a (Chl a) concentrations, was not significant $(r=0.13$, P-value $=0.126)$. This indicated that environmental parameters did not shape the genetic distances between isolated stations. The distance based redundancy analysis (dbRDA, P-value $=0.058$ ) showed a slight segregation of photic and aphotic samples, but not a clear separation between samples from different oceanographic regions, except for those of the Mediterranean, as seen also in Figure $5 \mathrm{~b}$. Temperature, salinity and $\mathrm{Chl}$ a accounted for a total of $21 \%$ of the observed variance with the first two axis explaining 17\% (Fig. 6b). Finally, when looking at the bathypelagic samples, the structure of OTUs belonging to individual samples was not evident based on their predominant water masses (Fig. 6c).

Despite the fact that we sampled very distant stations with contrasted environmental conditions and depths (photic vs aphotic), we found that $37 \%$ of the isolates (578 out of 1561 ), affiliating to 10 different genera, were $100 \%$ identical at their partial $16 \mathrm{~S}$ rRNA genes. This percentage increased to $45.7 \%$ (374 out of 819 total sequences), affiliating to 13 genera when comparing photic-layer and bathypelagic isolates coming from neighbouring stations, and was even higher, up to $58.9 \%$, when considering all OMZ and bathypelagic samples as aphotic and comparing them to all the photic samples. In all cases, we found Alteromonas, Cobetia, Erythrobacter, Leeuwenhoekiella, Halomonas, Idiomarina, Marinobacter, and Mesonia between the shared genera, indicating a cosmopolitan distribution.

\section{Novelty of the isolates}

The percentages of similarity between the strains and their Closest Cultured Match (CCM) and Closest Environmental Match (CEM) were extracted and compared with the $97 \%$ and $99 \%$ identity thresholds to explore the possible novelty of our culture collection. The results showed that most of the isolates were similar to previously published cultured bacterial species, but also to environmental sequences obtained using molecular techniques (Fig. 7a). Therefore, most of the isolates were previously known microorganisms. However, we detected three $100 \%$ identical strains in their partial $16 \mathrm{~S}$ rRNA gene that had a percentage of identity, both for CCM and CEM, below the threshold, at around $94 \%$. One of the strains was isolated from surface samples of the North Atlantic Ocean (ISS653), whereas the other two were isolated from two oxygen minimum samples of the Pacific Ocean (ISS1889, ISS2026). Further analyses with the complete 16S rRNA gene of one of those three strains indicated that they could be 
candidates to be a new specie or even a new genus according to the thresholds proposed by Yarza et al. [60]. The three databases consulted (NCBI, RDP, Silva) showed different BLASTn results (Table S15). Nevertheless, the Living Tree Project (LTP) database, which contains the accepted type species of each genus, showed a $93.5 \%$ similarity with Mesonia mobilis. The phylogenetic tree constructed (Fig. 7b) also supported its novelty as our isolate had less than $93.8 \%$ of similarity with the cultivated reference genomes of the Mesonia genus.

\section{Discussion}

Richness and abundances of culturable heterotrophic isolates

The rarefaction curves for photic-layer, OMZ, and bathypelagic samples for the isolates dataset did not reach saturation indicating that diversity was higher at all depths. Taking the more restrictive clustering of the isolates sequences (OTUs100), species richness (Chao-1, ACE) increased with depth (from 140 to photic up to 174 at the bathypelagic), and this pattern is coherent with the patterns observed using fragments of 16S rRNA genes directly from metagenomes (16S miTAGs) at global scale [3]. However, ShannonWeaver and Simpson indices that incorporate both richness and evenness were slightly higher for photic (4) than aphotic layers (OMZ (3.55) and bathypelagic (3.87)). Rank abundance curves from different layers showed that the heterotrophic isolates were composed by a few abundant OTUs with a large number of strains and many rare low abundant OTUs (Fig. 2c-d), which is also consistent with many other previous findings based on environmental samples [1, 8]. For instance, the 7 most abundant OTUs (99\%) accounted for $41 \%$ of the total sequences and similar proportions were found in each layer. Hence, $30 \%$ of the bathypelagic isolates, $47 \%$ of the OMZ isolates, and $43 \%$ of the photic isolates affiliated with these seven most abundant OTUs.

Relevance of dispersal along the oceanic water column within heterotrophic culturable bacteria

Small-sized planktonic organisms, such as the prokaryotes, are expected to have a great capacity of dispersion [61-63], more than those of larger planktonic organisms [63, 64]. Indeed, dispersal limitation tends to increase with body size in planktonic communities $[62,63,65]$. Due to the significant overlap between photic, OMZ and bathypelagic isolates, mainly those affiliating to genera Alteromonas, Halomonas, Marinobacter and Erythrobacter, our results suggest that these heterotrophic bacteria are well adapted to live in both environments (photic and aphotic), and therefore adapted to different temperatures, light and pressure. Moreover, they probably have versatile metabolisms 
to respond to different environments and nutrient availability. These characteristics may make these bacteria more prone to be successfully dispersed by the ocean circulation. In addition, genomic comparison between cultured isolates and uncultured genomes retrieved by single amplified genomes (SAGs) from marine environments revealed that the genomes of the cultures had larger sizes, suggesting a predominant copiotrophic lifestyle [66]. One possible explanation supporting the high proportion of identical 16S rRNA gene sequences between isolates of photic and deep-sea layers would be that these bacteria have the capacity to attach and grow on particles in the photic layers and after sinking to the deep ocean, they still retain the capability for further growth. Certainly, a recent study claimed that the particle colonization process that takes places in the photic-layers determines the composition of deeper layers and especially bathypelagic communities, and thus, photic and deep-ocean prokaryotic communities are strongly connected via sinking particles [11]. Moreover, the attachment to particles and its presence in the deep ocean has been described at least for Alteromonas sp. [11, 6769], Erythrobacter sp. and Halomonas sp. [11]. The higher metabolic versatility [66] and dormancy capability in the culturable rare bacterial taxa may be crucial to face such long vertical dispersion [70].

Using the partial sequences of the 16S rRNA gene, we did not find significant differences in the genetic distance between isolates that covered a wide latitudinal and geographical distance. Thus, culturable heterotrophic bacteria are not limited by dispersion. Certainly, the timeframes of a few thousand years for complete ocean water turnover [71], could also support the idea of homogenization of microbial populations and the high degree of biogeographical dispersion, as observed for the cosmopolitan genera described. Nevertheless, we also detected taxa present in only a few locations, such as Vibrio, isolated only in our survey in the photic North Western Mediterranean Sea, that are probably well adapted to specific niches. In this case, our results are in agreement with the famous sentence "everything is everywhere, but the environment selects" [72].

\section{Extent of cosmopolitan and locally cultured bacteria}

As we already mentioned, our results identified Alteromonas, Erythrobacter, Marinobacter and Halomonas as the most abundant cultured OTUs and widely distributed genera in our dataset. We classified the first two as cosmopolitan taxa and the last two as regional taxa, based on the classification proposed in the study of Gregory et al. [59]. These genera have been detected in other culture-dependent and cultureindependent studies from a wide variety of marine environments, including coastal, shelf, and open ocean waters $[9,13,16,69,73-75]$ corroborating their ubiquity. 
Alteromonas and Erythrobacter presented the highest number of isolates. Alteromonas is among the most common culturable heterotrophic bacteria living in open marine waters all around the world, as it has been isolated from a wide variety of marine environments [20,76-79]. In addition, this genus is thought to be one of the most significant contributors of the dissolved organic carbon (DOC) consumption and nutrient mineralization in the upper ocean [80]. Erythrobacter strains are aerobic chemoorganotrophs, and some species contain bacteriochlorophyll a, responsible for the aerobic anoxygenic phototrophic (AAP) metabolism [75].

Some culturable OTUs had a restricted distribution, appearing only in very low numbers or in only one of the samples. However, some of these, such as the genera Roseivirga or Winogradskyella, found only in surface waters of the Atlantic Ocean, Polaribacter, only retrieved from surface NW Mediterranean waters or Novosphingobium, isolated from deep waters of the South Atlantic, had previously been described in other culturedependent studies from other oceanographic locations [81-85]. Additionally, metadata information retrieved from the Closest Cultured Match and Closest Environmental Match of each one of the strains (Table S3 and S4) also indicated the presence of such restricted genera in other depths and oceanographic regions. Thus, these "local" OTUs are not restricted to the locations where we retrieved them, but the environmental conditions during the sampling and the culturing media used in the study allowed them to be retrieved only from certain samples.

\section{Novelty in the isolates}

There are several well-accepted criteria for the classification of bacteria into species and these include: (i) 70\% DNA-DNA hybridization [86], (ii) average nucleotide identity of shared genes (ANI) with a threshold around 94-96\% [87], and (iii) 16S rRNA gene sequence identity with a threshold at around $98.7 \%-99 \%[46,60,88]$. In order to further classify bacteria into high taxonomic ranks, Yarza et al. [60] proposed the following taxonomic thresholds for Bacteria and Archaea classification based on 16S rRNA sequence similarity: genera $94.5 \%$, families $86.5 \%$, orders $82.0 \%$, classes $78.5 \%$ and phyla $75 \%$. Three strains of our culture collection, $100 \%$ similar among them in their $16 \mathrm{~S}$ rRNA gene, presented less than $95 \%$ of similarity in their 16 S sequence to any previously described bacterial species and likely represent a novel species or even a new genus, because they are close to the genus threshold. Interestingly, isolate ISS653, was obtained from the North Atlantic waters whereas ISS1889 and ISS2026 were retrieved from oxygen minimum zone areas of the Pacific Ocean, suggesting that this novel species is not locally restricted. The strains possibly belong to the genus Mesonia. 
Members of this taxon are mainly retrieved from a variety of marine environments, sometimes associated with eukaryotic organisms, such as algae [89].

\section{Conclusions}

Culturing remains an important tool in microbial ecology, helping to map the diversity of marine communities, but also to describe the diversity patterns of that fraction of the bacterioplankton community that can be accessed through isolation. Equally to those high-throughput sequencing studies of ribosomal genes targeting the whole marine prokaryotic community, we found that culturable marine heterotrophic bacteria present few abundant taxa and a tail of rare and low abundant OTUs. We detected that half of the total isolates were shared in the three different depth realms, reinforcing the idea of vertical connectivity between the photic and the deep ocean probably through sinking particles. In addition, we identified Alteromonas and Erythrobacter genera to be cosmopolitan because they were isolated from more than $80 \%$ of the studied samples and from all layers. Finally, we did not find any correlation between genetic distances and depth or geographic distance supporting the idea of high dispersal of the marine heterotrophic culturable microorganisms.

\section{Acknowledgments}

We are grateful to Elisabet Laia Sà for her help along the culturing processes and Vanessa Balagué for helping in the laboratory. We thank our fellow scientists and the crew and chief scientists of the different cruise legs for the smooth operation in the ATP, MIFASOL and Malaspina expeditions. We thank the people and sponsors who participated in the Tara Oceans Expedition 2009-2013 (http://oceans.taraexpeditions.org) for collecting some of the samples for culturing used in this study. This is Tara Oceans contribution paper number XX. The project Malaspina 2010 Expedition (ref. CSD2008-00077) was funded by the Spanish Ministry of Economy and Competitiveness, Science and Innovation through the Consolider-Ingenio programme. Research was mainly funded by grant BIOSENSOMICS "Convocatoria 2015 de ayudas Fundación BBVA a investigadores y creadores culturales" and, MAGGY Plan Nacional I+D+I 2017 (CTM2017-87736-R) to SGA and the King Abdullah University of Science and Technology (KAUST) through baseline funding to C.M. Duarte and a subaward agreement OSR-2014-CC-1973-02 between KAUST and Universitat Autònoma de Barcelona (UAB). Additional funding was provided by projects REMEI (ref. CTM2015-70340-R) from the Spanish Ministry of Economy and Competitiveness, Arctic 
Tipping Points (ATP, contract \#226248) in the FP7 program of the European Union, and DOREMI (CTM2012-34294).

\section{References}

1. Sogin ML, Morrison HG, Huber JA, et al (2006) Microbial diversity in the deep sea and the underexplored "rare biosphere". Proc Natl Acad Sci U S A 103:1211512120. https://doi.org/10.1073/pnas.0605127103

2. Zinger L, Amaral-Zettler LA, Fuhrman JA, et al (2011) Global patterns of bacterial beta-diversity in seafloor and seawater ecosystems. PLoS One 6:e24570. https://doi.org/10.1371/journal.pone.0024570

3. Sunagawa S, Coelho LP, Chaffron S, et al (2015) Structure and function of the global ocean microbiome. Science 348(6237):1261359. https://doi:10.1126/science.1261359.

4. Pedrós-Alió C, Acinas SG, Logares R, Massana R (2018) Marine microbial diversity as seen by high-throughput sequencing. In: Gasol JM, Kirchman DL (eds) Microbial Ecology of the Oceans, 3rd edn. Wiley-Blackwell, Hoboken, pp 47-98

5. DeLong EF, Preston CM, Mincer T, et al (2006) Community genomics among stratified microbial assemblages in the ocean's interior. Science 311:496-503. https://doi.org/10.1126/science.1120250

6. Hewson I, Steele JA, Capone DG, Fuhrman JA (2006) Remarkable heterogeneity in meso- and bathypelagic bacterioplankton assemblage composition. Limnol Oceanogr 51:1274-1283. https://doi.org/10.4319/lo.2006.51.3.1274

7. Terahara T, Yamada K, Nakayama J, et al (2016) Bacterial community structures of deep-sea water investigated by molecular biological techniques. Gene 576:696-700. https://doi.org/10.1016/J.GENE.2015.10.027

8. Pedrós-Alió C (2012) The rare bacterial biosphere. Ann Rev Mar Sci 4:449-466. https://doi.org/10.1146/annurev-marine-120710-100948

9. Crespo BG, Wallhead PJ, Logares R, Pedrós-Alió C (2016) Probing the rare biosphere of the North- West Mediterranean sea: An experiment with high sequencing effort. PLoS One 1-16. https://doi.org/10.1371/journal.pone.0159195

10. Pommier T, Neal PR, Gasol JM, et al (2010) Spatial patterns of bacterial richness and evenness in the NW Mediterranean Sea explored by pyrosequencing of the 16S rRNA. Aquat Microb Ecol 61:221-233. https://doi.org/10.3354/ame01484

11. Mestre M, Ruiz-González C, Logares R, et al (2018) Sinking particles promote vertical connectivity in the ocean microbiome. Proc Natl Acad Sci U S A 
115:E6799-E6807. https://doi.org/10.1073/pnas.1802470115

12. Zinger L, Boetius A, Ramette A (2014) Bacterial taxa-area and distance-decay relationships in marine environments. Mol Ecol 23:954-964. https://doi.org/10.1111/mec. 12640

13. Salazar G, Cornejo-Castillo FM, Benítez-Barrios V, et al (2016) Global diversity and biogeography of deep-sea pelagic prokaryotes. ISME J 596-608. https://doi.org/10.1038/ismej.2015.137

14. Pommier T, Canbäck B, Riemann L, et al (2007) Global patterns of diversity and community structure in marine bacterioplankton. Mol Ecol 16:867-880. https://doi.org/10.1111/j.1365-294X.2006.03189.x

15. Hagström Å, Pinhassi J, Zweifel LU (2000) Biogeographical diversity among marine bacterioplankton. Microb Ecol 21:231-244

16. Lekunberri I, Gasol JM, Acinas SG, et al (2014) The phylogenetic and ecological context of cultured and whole genome-sequenced planktonic bacteria from the coastal NW Mediterranean Sea. Syst Appl Microbiol 37:216-228. https://doi.org/10.1016/j.syapm.2013.11.005

17. Pinhassi J, Zweifel UL, Hagström $\AA$ (1997) Dominant marine bacterioplankton species found among colony-forming bacteria. Appl Environ Microbiol 63:33593366

18. Eilers H, Pernthaler J, Glöckner FO, Amann R (2000) Culturability and in situ abundance of pelagic bacteria from the North Sea. Appl Environ Microbiol 66:3044-3051. https://doi.org/10.1128/AEM.66.7.3044-3051.2000

19. Yang S-J, Kang I, Cho J-C (2016) Expansion of cultured bacterial diversity by large-scale dilution-to-extinction culturing from a single seawater sample. Microb Ecol 71:29-43. https://doi.org/10.1007/s00248-015-0695-3

20. Kai W, Peisheng Y, Rui M, et al (2017) Diversity of culturable bacteria in deepsea water from the South Atlantic Ocean. Bioengineered 8:572-584. https://doi.org/10.1080/21655979.2017.1284711

21. Liu Q, Fang J, Li J, et al (2018) Depth-resolved variations of cultivable bacteria and their extracellular enzymes in the water column of the New Britain Trench. Front Microbiol 9:135. https://doi.org/10.3389/fmicb.2018.00135

22. Castro Da Silva MA, Cavalett A, Spinner A, et al (2013) Phylogenetic identification of marine bacteria isolated from deep-sea sediments of the eastern South Atlantic Ocean. Springerplus 2:127. doi:10.1186/2193-1801-2-127.

23. Nakagawa S, Takai K (2008) Deep-sea vent chemoautotrophs: diversity, biochemistry and ecological significance. FEMS Microbiol Ecol 65:1-14. https://doi.org/10.1111/j.1574-6941.2008.00502.x 
24. Ferrera I, Banta AB, Reysenbach AL (2014) Spatial patterns of Aquificales in deep-sea vents along the Eastern Lau Spreading Center (SW Pacific). Syst Appl Microbiol 37:442-448. https://doi.org/10.1016/j.syapm.2014.04.002

25. Grosche A, Sekaran H, Pérez-Rodríguez I, et al (2015) Cetia pacifica gen. nov., sp. nov., a chemolithoautotrophic, thermophilic, nitrate-ammonifying bacterium from a deep-sea hydrothermal vent. Int J Syst Evol Microbiol 65:1144-1150. https://doi.org/10.1099/ijs.0.000070

26. Tringe SG, von Mering C, Kobayashi A, et al (2005) Comparative metagenomics of microbial communities. Science (80- ) 308:554-557. https://doi.org/10.1126/science.1107851

27. Eloe EA, Shulse CN, Fadrosh DW, et al (2011) Compositional differences in particle-associated and free-living microbial assemblages from an extreme deepocean environment. Environ Microbiol Rep 3:449-458. https://doi.org/10.1111/j.1758-2229.2010.00223.x

28. Zobell CE, Morita RY (1957) Barophilic bacteria in some deep sea sediments. J Bacteriol 73:563-568

29. Hwang CY, Lee I, Cho Y, et al (2015) Sediminicola arcticus sp. nov., a psychrophilic bacterium isolated from deep-sea sediment, and emended description of the genus Sediminicola. Int J Syst Evol Microbiol 65:1567-1571. https://doi.org/10.1099/ijs.0.000138

30. Chen P, Zhang L, Guo X, et al (2016) Diversity, biogeography, and biodegradation potential of Actinobacteria in the deep-sea sediments along the Southwest Indian Ridge. Front Microbiol 7:1340. https://doi.org/10.3389/fmicb.2016.01340

31. Sahm K, Knoblauch C, Amann R (1999) Phylogenetic affiliation and quantification of psychrophilic sulfate-reducing isolates in marine Arctic sediments. Appl Environ Microbiol 65:3976-3981

32. Finster KW, Kjeldsen KU (2010) Desulfovibrio oceani subsp. oceani sp. nov., subsp. nov. and Desulfovibrio oceani subsp. galateae subsp. nov., novel sulfatereducing bacteria isolated from the oxygen minimum zone off the coast of Peru. Antonie van Leeuwenhoek 97:221-229. https://doi.org/10.1007/s10482-0099403-y

33. Mulla A, Fernandes G, Menezes L, et al (2018) Diversity of culturable nitratereducing bacteria from the Arabian Sea oxygen minimum zone. Deep Res Part II Top Stud Oceanogr 156:27-33. https://doi.org/10.1016/j.dsr2.2017.12.014

34. Menezes L, Fernandes G, Mulla A, et al (2018) Diversity of culturable Sulphuroxidising bacteria in the oxygen minimum zones of the northern Indian Ocean. $J$ Mar Syst 0-1. https://doi.org/10.1016/j.jmarsys.2018.05.007 
35. Tabor PS, Ohwada K, Colwell RR (1981) Filterable marine bacteria found in the deep sea: distribution, taxonomy, and response to starvation. Microb Ecol 7:6783. https://doi.org/10.1007/BF02010479

36. Kaye JZ, Baross JA (2000) High incidence of halotolerant bacteria in Pacific hydrothermal-vent and pelagic environments. FEMS Microbiol Ecol 32:249-260

37. Yuan J, Lai Q, Sun F, et al (2015) The diversity of PAH-degrading bacteria in a deep-sea water column above the southwest Indian ridge. Front Microbiol 6:1-12. https://doi.org/10.3389/fmicb.2015.00853

38. Karsenti E, Acinas SG, Bork P, et al (2011) A holistic approach to marine ecosystems biology. PLoS Biol 9:7-11. https://doi.org/10.1371/journal.pbio.1001177

39. Lara E, Arrieta JM, Garcia-Zarandona I, et al (2013) Experimental evaluation of the warming effect on viral, bacterial and protistan communities in two contrasting Arctic systems. Aquat Microb Ecol 70:17-32. https://doi.org/10.3354/ame01636

40. Duarte CM (2015) Seafaring in the 21St Century: The Malaspina 2010 circumnavigation expedition. Limnol Oceanogr Bull 24:11-14. https://doi.org/10.1002/lob.10008

41. Villar E, Farrant GK, Follows M, et al (2015) Environmental characteristics of Agulhas rings affect interocean plankton transport. Science (80- ) 348:12614471261447. https://doi.org/10.1126/science.1261447

42. Zobell CE (1941) Studies on marine bacteria. I. The requirements of heterotrophic aerobes. J Mar Res 4:42-75

43. Muyzer G, de Waal EC, Uitterlinden AG (1993) Profiling of complex microbial populations by denaturing gradient gel electrophoresis analysis of polymerase chain reaction-amplified genes coding for 16S rRNA. Appl Environ Microbiol 59:695-700

44. Sánchez O, Gasol JM, Massana R, et al (2007) Comparison of different denaturing gradient gel electrophoresis primer sets for the study of marine bacterioplankton communities. Appl Environ Microbiol 73:5962-5967. https://doi.org/10.1128/AEM.00817-07

45. Page KA, Connon SA, Giovannoni SJ (2004) Representative freshwater bacterioplankton isolated from Crater Lake, Oregon. Appl Environ Microbiol 70:6542-6550. https://doi.org/10.1128/AEM.70.11.6542-6550.2004

46. Acinas SG, Klepac-Ceraj V, Hunt DE (2003) Fine-scale phylogenetic architecture of a complex bacterial community. Nature 104:551-554

47. Edgar RC (2010) Search and clustering orders of magnitude faster than BLAST. Bioinformatics 26:2460-2461. https://doi.org/10.1093/bioinformatics/btq461

48. Pruesse E, Peplies J, Glöckner FO (2012) SINA: accurate high-throughput 
multiple sequence alignment of ribosomal RNA genes. Bioinformatics 28:18231829. https://doi.org/10.1093/bioinformatics/bts25

49. Altschul SF, Gish W, Miller W, et al (1990) Basic local alignment search tool. J Mol Biol 215:403-410. https://doi.org/10.1016/S0022-2836(05)80360-2

50. Salazar $\mathrm{G}$ (2018) EcolUtils: Utilities for community ecology analysis. R package version 0.1. https://github.com/GuillemSalazar/EcolUtils

51. Oksanen J, Blanchet FG, Friendly M, et al (2018) vegan: community ecology package. R package version 2.5-3. https://CRAN.R-project.org/package=vegan

52. Giovannoni SJ, Mullins TD, Field KG (1995) Microbial diversity in oceanic systems: rRNA approaches to the study of unculturable microbes. In: Joint I (eds) Molecular ecology of aquatic microbes. NATO ASI Series (Series G: Ecological Sciences), vol 38. Springer, Berlin, Heidelberg, pp 217-248

53. R Core Team (2017) R: A language and environment for statistical computing. $R$ foundation for statistical computing, Vienna, Austria. https://www.R-project.org/.

54. Tamura K, Peterson D, Peterson N, et al (2011) MEGA5: molecular evolutionary genetics analysis using maximum likelihood, evolutionary distance, and maximum parsimony methods. Mol Biol Evol 28:2731-9. https://doi.org/10.1093/molbev/msr121

55. Kembel SW, Cowan PD, Helmus MR, et al (2010) Picante: $R$ tools for integrating phylogenies and ecology. Bioinformatics 26:1463-1464

56. Minchin PR (1987) An evaluation of the relative robustness of techniques for ecological ordination. Vegetatio 69:89-107

57. Paradis E, Claude J, Strimmer K (2004) APE: analyses of phylogenetics and evolution in $R$ language. Bioinformatics 20:289-290. https://doi.org/10.1093/bioinformatics/btg412

58. Legendre, Pierre LL (1988) Numerical Ecology. Dev Environ Model. Elsevier.The Netherlands.

59. Gregory AC, Zayed AA, Conceição-Neto N, et al (2019) Marine DNA viral macroand microdiversity from pole to pole. Cell. doi:10.1016/j.cell.2019.03.040

60. Yarza P, Yilmaz P, Pruesse E, et al (2014) Uniting the classification of cultured and uncultured bacteria and archaea using 16S rRNA gene sequences. Nat Rev Microbiol 12:635-645. https://doi.org/10.1038/nrmicro3330

61. Finlay BJ, Esteban GF, Fenchel T (1996) Global diversity and body size. Nature 383:132-133. https://doi.org/10.1038/383132a0

62. Finlay BJ (2002) Global dispersal of free-living microbial eukaryote species. Science 296:1061-1063. https://doi.org/10.1126/science.1070710

63. Villarino E, Watson JR, Jönsson B, et al (2018) Large-scale ocean connectivity 
and planktonic body size. Nat Commun 9:142. https://doi.org/10.1038/s41467017-02535-8

64. Martiny JB, Bohannan BJ, Brown JH, et al (2006) Microbial biogeography: putting microorganisms on the map. Nat Rev Microbiol 4:102-112. https://doi.org/10.1038/nrmicro1341

65. Soininen J, Korhonen JJ, Luoto M (2013) Stochastic species distributions are driven by organism size. Ecology 94:660-670. https://doi.org/10.1890/12-0777.1

66. Swan BK, Tupper B, Sczyrba A, et al (2013) Prevalent genome streamlining and latitudinal divergence of planktonic bacteria in the surface ocean. Proc Natl Acad Sci U S A 110:11463-11468. https://doi.org/10.1073/pnas.1304246110

67. Acinas SG, Antón J, Rodríguez-Valera F (1999) Diversity of free-living and attached bacteria in offshore Western Mediterranean waters as depicted by analysis of genes encoding 16S rRNA. Appl Environ Microbiol 65:514-522

68. Crespo BG, Pommier T, Fernández-Gómez B, Pedrós-Alió C (2013) Taxonomic composition of the particle-attached and free-living bacterial assemblages in the Northwest Mediterranean Sea analyzed by pyrosequencing of the 16S rRNA. Microbiology open 2:541-552. https://doi.org/10.1002/mbo3.92

69. Salazar G, Cornejo-Castillo FM, Borrull E, et al (2015) Particle-association lifestyle is a phylogenetically conserved trait in bathypelagic prokaryotes. Mol Ecol 56925706. https://doi.org/10.1111/mec.13419

70. Jones SE, Lennon JT (2010) Dormancy contributes to the maintenance of microbial diversity. Proc Natl Acad Sci U S A 107:5881-5886. https://doi.org/10.1073/pnas.0912765107

71. Döös K, Nilsson J, Nycander J, et al (2012) The world ocean thermohaline circulation. J Phys Oceanogr 42:1445-1460. https://doi.org/10.1175/JPO-D-110163.1

72. Baas Becking LGM (1934) Geobiologie of inleiding tot de milieukunde. The Hague, The Netherlands: WP. Van Stockum \& Zoon (in Dutch)

73. Selje N, Brinkhoff T, Simon M (2005) Detection of abundant bacteria in the Weser estuary using culture-dependent and culture-independent approaches. Aquat Microb Ecol 39:17-34. https://doi.org/10.3354/ame039017

74. Zeng Y, Zou Y, Grebmeier JM, et al (2012) Culture-independent and -dependent methods to investigate the diversity of planktonic bacteria in the northern Bering Sea. Polar Biol 35:117-129. https://doi.org/10.1007/s00300-011-1044-8

75. Tonon LAC, Moreira APB, Thompson F (2014) The Family Erythrobacteraceae. In: Rosenberg E, DeLong EF, Lory S, Stackebrandt E, Thompson F. (eds) The Prokaryotes. Springer, Berlin, Heidelberg. pp 213-235 
76. Baumann L, Baumann P, Mandel M, Allen RD (1972) Taxonomy of aerobic marine eubacteria. J Bacteriol 110:402-429

77. Fuhrman JA, Davis AA (1997) Widespread Archaea and novel Bacteria from the deep sea as shown by 16 S rRNA gene sequences. Mar Ecol Prog Ser 150:275285. https://doi.org/10.3354/meps 150275

78. García-Martínez J, Acinas SG, Massana R, Rodríguez-Valera F (2002) Prevalence and microdiversity of Alteromonas macleodii-like microorganisms in different oceanic regions. Environ Microbiol 4:42-50

79. Gärtner A, Blümel M, Wiese J, Imhoff JF (2011) Isolation and characterisation of bacteria from the Eastern Mediterranean deep sea. Antonie van Leeuwenhoek 100:421-435. https://doi.org/10.1007/s10482-011-9599-5

80. Pedler BE, Aluwihare LI, Azam F (2014) Single bacterial strain capable of significant contribution to carbon cycling in the surface ocean. Proc Natl Acad Sci 111:7202-7207. https://doi.org/10.1073/pnas.1401887111

81. Gosink JJ, Woese CR, Staley JT (1998) Polaribacter gen. nov., with three new species, P. irgensii sp. nov., P. franzmannii sp. nov. and P. filamentus sp. nov., gas vacuolate polar marine bacteria of the Cytophaga-FlavobacteriumBacteroides group and reclassification of "Flectobacillus glomeratus" as Polaribacter glomeratus comb. nov. Int J Syst Bacteriol 48:223-235. https://doi.org/10.1099/00207713-48-1-223

82. Kumagai C, Yoshizawa S, Oshima K, et al (2014) Complete genome sequence of Winogradskyella sp. strain PG-2, a proteorhodopsin-containing marine flavobacterium. Genome Announc 2:490-504

83. Selvaratnam C, Thevarajoo S, Goh KM, et al (2016) Proposal to reclassify Roseivirga ehrenbergii (Nedashkovskaya et al., 2008) as Roseivirga seohaensis comb. nov., description of Roseivirga seohaensis subsp. aquiponti subsp. nov. and emendation of the genus Roseivirga. Int J Syst Evol Microbiol 66:5537-5543. https://doi.org/10.1099/ijsem.0.001553

84. Kumar R, Verma H, Haider S, et al (2017) Comparative genomic analysis reveals habitat-specific genes and regulatory hubs within the genus Novosphingobium. mSystems 2:e00020-17. https://doi.org/10.1128/mSystems.00020-17

85. Caruso C, Rizzo C, Mangano S, et al (2018) Production and biotechnological potential of extracellular polymeric substances from sponge-associated Antarctic bacteria. Appl Environ $\quad$ Microbiol $01624-17$. https://doi.org/10.1128/AEM.01624-17

86. Wayne LG, Brenner DJ, Colwell RR, et al (1987) Report of the Ad hoc committee on reconciliation of approaches to bacterial systematics. Int J Syst Bacteriol 


\section{7:463-464}

87. Richter M, Rosselló-Móra R (2009) Shifting the genomic gold standard for the prokaryotic species definition. Proc Natl Acad Sci U S A 106:19126-19131. https://doi.org/10.1073/pnas.0906412106

88. Stackebrandt E, Eibers J (2006) Taxonomic parameters revisited: tarnished gold standards. Microbiol Today 33:152-155

89. Nedashkovskaya OI, Kim SB, Zhukova N V, et al (2006) Mesonia mobilis sp. nov., isolated from seawater, and emended description of the genus Mesonia. Int J Syst Evol Microbiol 56:2433-2436. https://doi.org/10.1099/ijs.0.64376-0 
Tables

Table 1. Characteristics of the different samples used for isolation of bacteria. Non-redundant isolates stand for those isolates in the same sample that presented $100 \%$ similarity in their partial $16 \mathrm{~S}$ rRNA sequences.

\begin{tabular}{|c|c|c|c|c|c|c|c|c|}
\hline Cruise & Station & Oceanic location & Latitude & Longitude & Depth (m) & $\begin{array}{c}\text { In situ } \\
\text { temperature } \\
(\stackrel{\circ}{ })\end{array}$ & $\begin{array}{c}\text { № of } \\
\text { sequenced } \\
\text { isolates }\end{array}$ & $\begin{array}{c}\text { № of non- } \\
\text { redundant } \\
\text { isolates }\end{array}$ \\
\hline \multirow{10}{*}{ Tara Oceans } & ST 39 & Indian Ocean & $19^{\circ} 2.24^{\prime} \mathrm{N}$ & $64^{\circ} 29.24^{\prime} \mathrm{E}$ & 5.5 & 26.2 & 104 & 25 \\
\hline & ST 39 & Indian Ocean & $18^{\circ} 35.2^{\prime} \mathrm{N}$ & 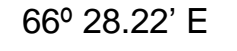 & 25 & 26.8 & 243 & 53 \\
\hline & ST 39 & Indian Ocean & $18^{\circ} 43.12^{\prime} \mathrm{N}$ & $66^{\circ} 21.3^{\prime} \mathrm{E}$ & 268.2 & 15.6 & 88 & 18 \\
\hline & ST 67 & South Atlantic & $32^{\circ} 17.31^{\prime} \mathrm{S}$ & $17^{\circ} 12.22^{\prime} \mathrm{E}$ & 5 & 12.8 & 115 & 49 \\
\hline & ST 72 & South Atlantic & $8^{\circ} 46.44^{\prime} \mathrm{S}$ & $17^{\circ} 54.36^{\prime} \mathrm{W}$ & 5 & 25 & 71 & 33 \\
\hline & ST 76 & South Atlantic & $20^{\circ} 56.7^{\prime} \mathrm{S}$ & $35^{\circ} 10.49^{\prime} \mathrm{W}$ & 5 & 23.3 & 89 & 27 \\
\hline & ST 151 & North Atlantic & $36^{\circ} 10.17^{\prime} \mathrm{N}$ & $29 \div 1.23^{\prime} \mathrm{W}$ & 5 & 17.3 & 76 & 33 \\
\hline & ST 102 & Pacific Ocean & $5^{\circ} 16.12^{\prime} \mathrm{S}$ & 85ำ 13.12' O & 475.6 & 9.2 & 97 & 15 \\
\hline & ST 111 & Pacific Ocean & $16^{\circ} 57.36^{\prime} \mathrm{S}$ & $100^{\circ} 39.36^{\prime} \mathrm{O}$ & 347.1 & 10.9 & 98 & 35 \\
\hline & ST 138 & Pacific Ocean & 6⒉ $22.12^{\prime} \mathrm{N}$ & $103^{\circ} 4.12^{\prime} \mathrm{O}$ & 444.9 & 8.2 & 79 & 34 \\
\hline \multirow{2}{*}{ ATP } & $A R \_1$ & Arctic Ocean & $78^{\circ} 20.00^{\prime} \mathrm{N}$ & $15^{\circ} 00.00^{\prime} \mathrm{E}$ & 2 & 6.2 & 13 & 9 \\
\hline & $A R \_2$ & Arctic Ocean & $76^{\circ} 28.65^{\prime} \mathrm{N}$ & 28우 $00.62^{\prime} \mathrm{E}$ & 25 & -1.2 & 20 & 9 \\
\hline \multirow{6}{*}{ Malaspina } & ST 10 & North Atlantic & $21^{\circ} 33.36^{\prime} \mathrm{N}$ & $23^{\circ} 26^{\prime} \mathrm{W}$ & 4002 & 2.04 & 20 & 9 \\
\hline & ST 17 & South Atlantic & $3^{\circ} 1.48$ ' S & $27^{\circ} 19.48^{\prime} \mathrm{W}$ & 4002 & 1.74 & 93 & 24 \\
\hline & ST 23 & South Atlantic & $15^{\circ} 49.48^{\prime} \mathrm{S}$ & $33^{\circ} 24.36^{\prime} \mathrm{W}$ & 4003 & 1.45 & 94 & 39 \\
\hline & ST 32 & South Atlantic & $26^{\circ} 56.8^{\prime} \mathrm{S}$ & $21^{\circ} 24^{\prime} \mathrm{W}$ & 3200 & 2.5 & 39 & 16 \\
\hline & ST 33 & South Atlantic & $27^{\circ} 33.2^{\prime} \mathrm{S}$ & $18^{\circ} 5.4^{\prime} \mathrm{W}$ & 3904 & 1.7 & 5 & 5 \\
\hline & ST 43 & South Atlantic & $32^{\circ} 48.8^{\prime} \mathrm{S}$ & $12^{\circ} 46.2^{\prime} \mathrm{E}$ & 4000 & 1.2 & 4 & 4 \\
\hline Mifasol & ST 8 & NW Mediterranean & $40^{\circ} 38.41^{\prime} \mathrm{N}$ & $2^{\circ} 50^{\prime} \mathrm{E}$ & 2000 & 13.2 & 127 & 36 \\
\hline BBMO & IBSURF & NW Mediterranean & $41^{\circ} 40^{\prime} \mathrm{N}$ & $2^{\circ} 48^{\prime} \mathrm{E}$ & 5 & 17.71 & 86 & 43 \\
\hline
\end{tabular}


Table 2. Richness, Diversity and Coverage of the isolates retrieved per depth. Results of diversity indices calculated with the OTU-abundance tables per layer constructed at $99 \%$ and $100 \%$ sequences similarity and rarefied down to the lowest isolated layer (OMZ with 362 isolates). OMZ: oxygen minimum zone; Singletons: OTUs appearing only once and S.obs: Observed species.

\begin{tabular}{|l|l|l|l||l|l|l|}
\cline { 2 - 4 } \multicolumn{1}{c|}{} & \multicolumn{9}{l||}{$99 \%$} & \multicolumn{1}{l|}{$\mathbf{1 0 0 \%}$} \\
\cline { 2 - 7 } \multicolumn{1}{c|}{} & Photic & OMZ & Bathypelagic & Photic & OMZ & Bathypelagic \\
\hline Number of isolates & 346 & 362 & 368 & 320 & 362 & 372 \\
\hline Number of OTUs & 61 & 57 & 59 & 95 & 80 & 98 \\
\hline Number of Singletons & 18 & 25 & 20 & 42 & 41 & 50 \\
\hline Coverage & $70.5 \%$ & $56.1 \%$ & $66.1 \%$ & $55.8 \%$ & $48.75 \%$ & $49 \%$ \\
\hline S.obs & 61 & 57 & 59 & 95 & 80 & 98 \\
\hline Chao1 & 71.2 & 99.9 & 74.8 & 140.31 & 162 & 174.6 \\
\hline ACE & 77.8 & 87.6 & 81.9 & 145.56 & 143.3 & 179.9 \\
\hline Shannon-Weaver & 3.4 & 3.15 & 3.3 & 4 & 3.5 & 3.87 \\
\hline Simpson & 0.95 & 0.92 & 0.94 & 0.97 & 0.94 & 0.96 \\
\hline
\end{tabular}




\section{Figures}

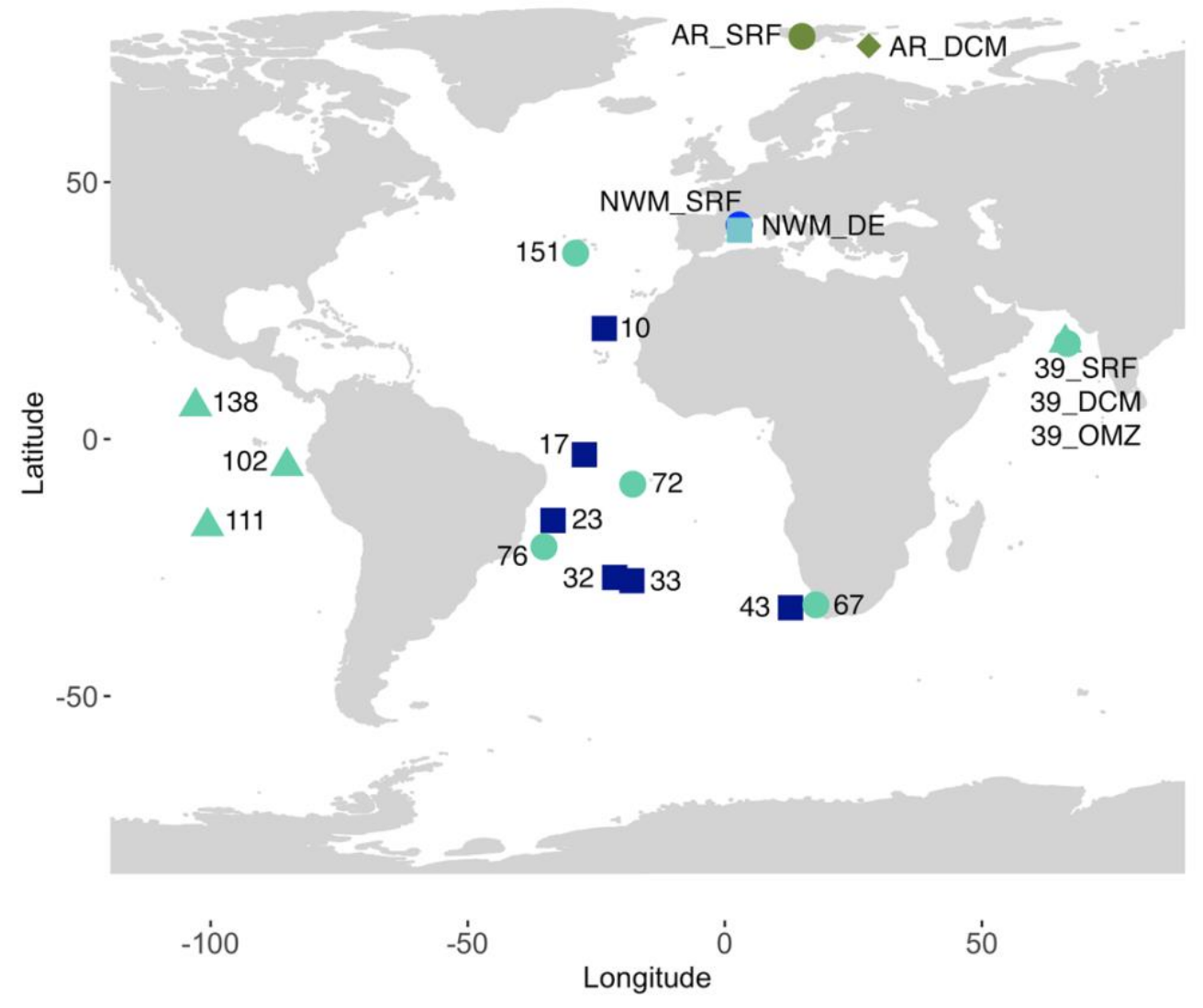

Fig. 1 Map showing the sampling stations of the present study. Circles indicate, surface stations; diamonds, deep chlorophyll maximum (DCM) stations; triangles, oxygen minimum zone (OMZ) stations; and squares, bathypelagic stations. The different colours indicate the oceanographic cruise in which the samples were collected: dark green, ATP09; blue, Blanes Bay Microbial Observatory (BBMO); dark blue, Malaspina; light blue, MIFASOL; and turquoise, Tara Oceans. 

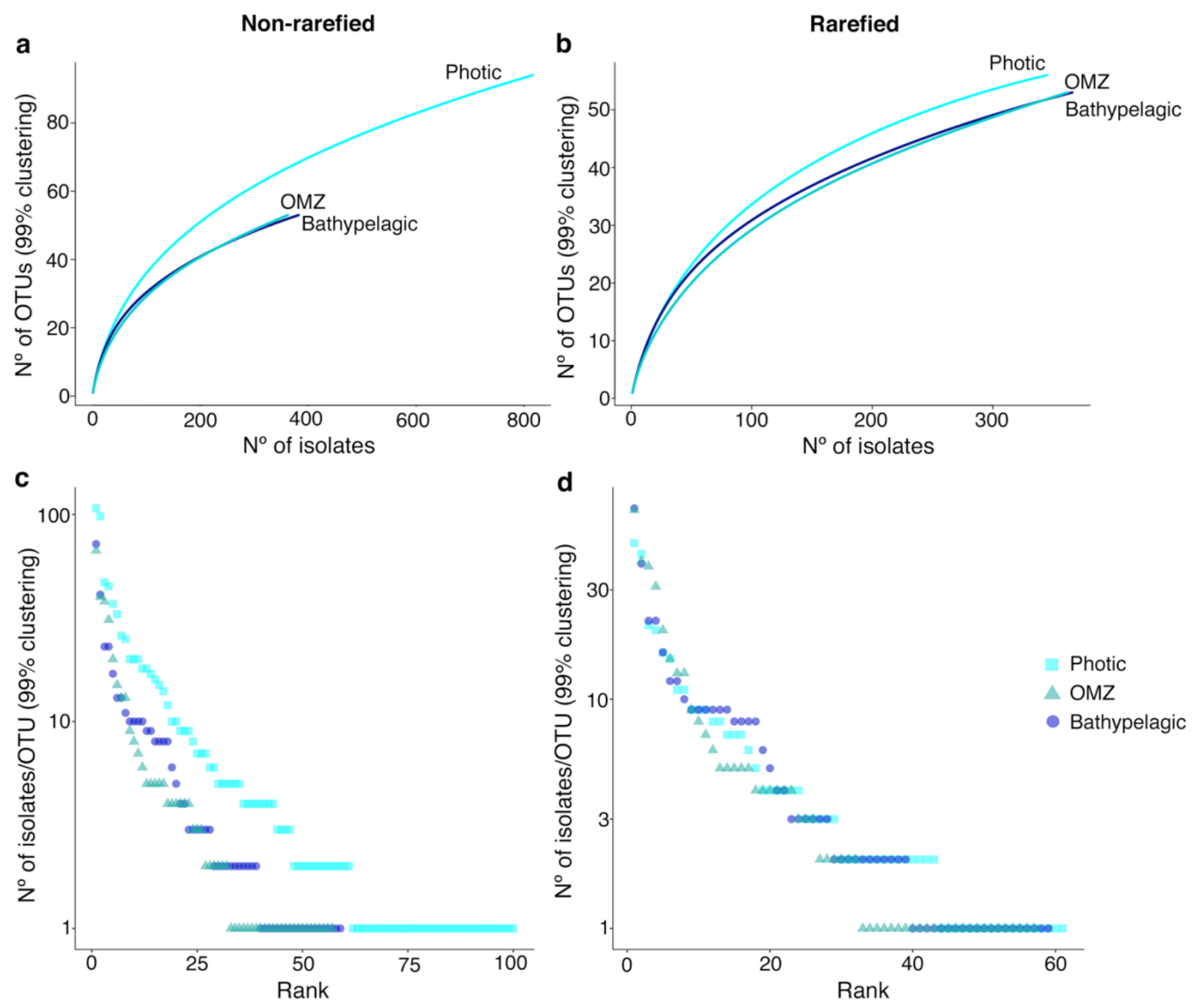

Fig. 2 (a-b) Rarefaction curves for photic, OMZ and bathypelagic samples extracted also from the non-rarefied and rarefied OTU table. (c-d) Rank abundance plots showing the number of isolates per OTU (at 99\% clustering) obtained in the three layers studied for non-rarefied OTU table, and rarefied OTU table down to the lowest isolated layer, in this case, the $\mathrm{OMZ}$ with 362 isolates. $Y$ axis are in $\log _{10}$ scale. Colour and shape indicate the layer where the OTUs were isolated: Photic-layer, light-blue squares; Oxygen minimum zone (OMZ), Turquoise triangles; and Bathypelagic ocean, dark blue circles. 


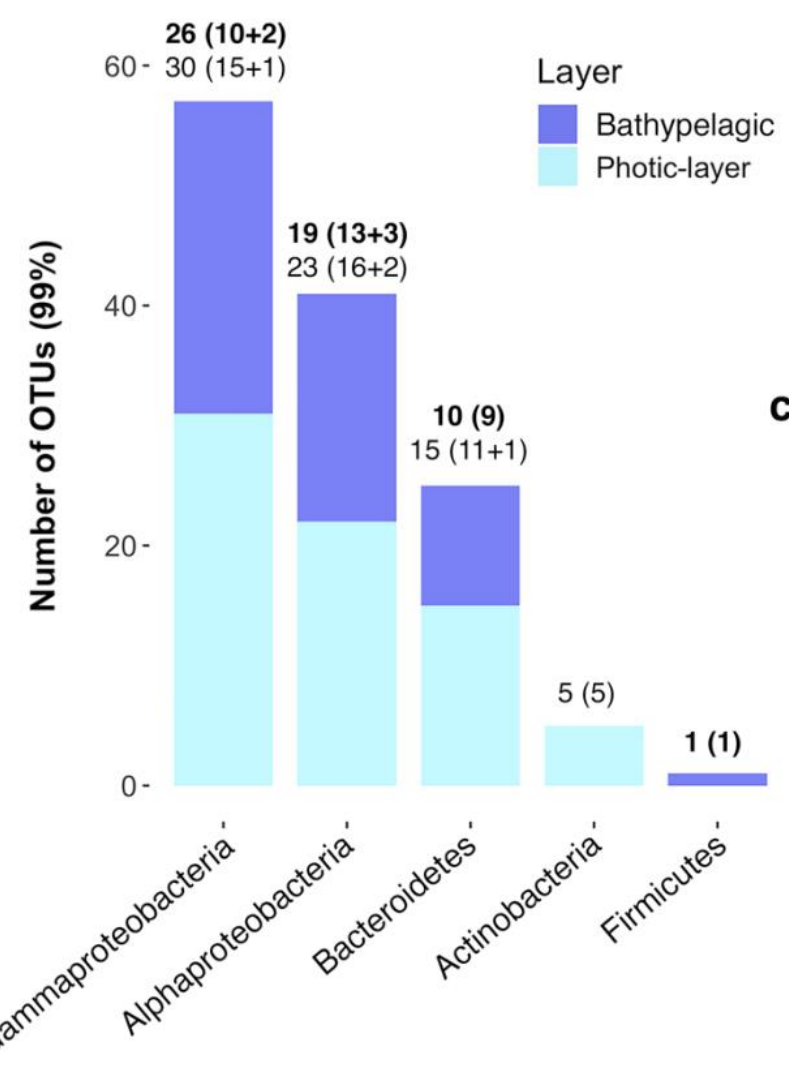

Photic-layer OTUs

Bathypelagic OTUs

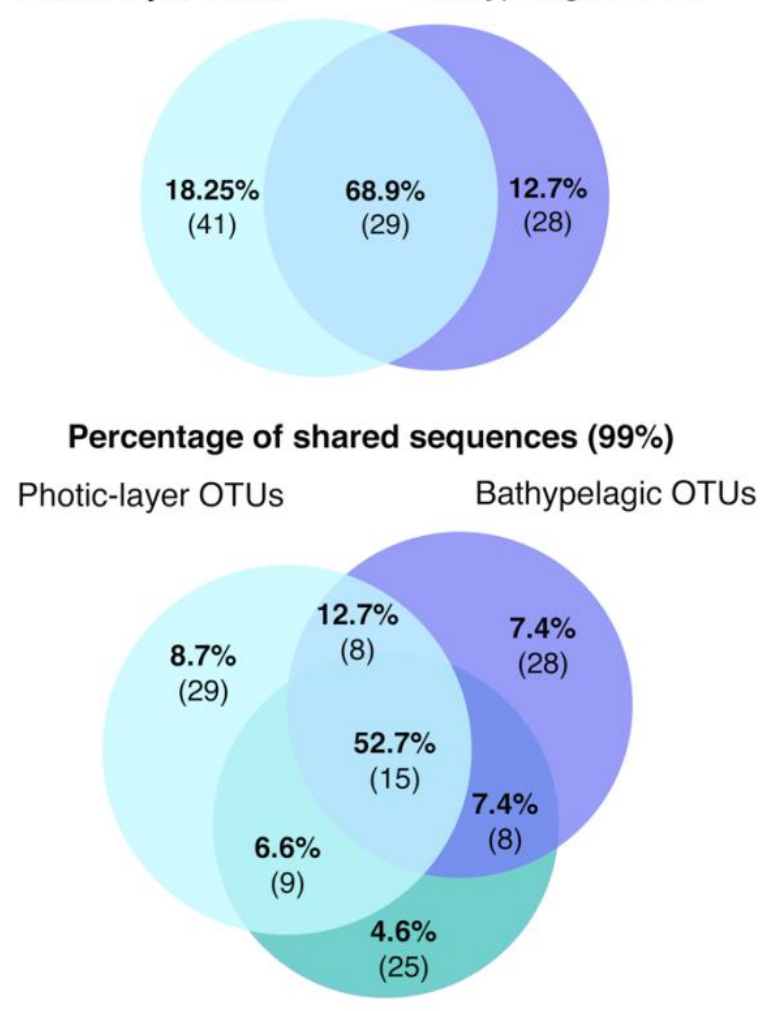

OMZ OTUs

Fig. 3 OTUs retrieved from photic-layer and deep-sea waters. (a) Phyla/Class retrieved per oceanic layer. Each bar of the plot represents a phylum, or class in the case of Proteobacteria. OTUs were defined by clustering at $99 \%$ sequence similarity. The dark blue represents the total number of OTUs retrieved from bathypelagic samples, whereas the light blue represents the total number of OTUs isolated from photic samples. The number of OTUs is shown above each bar. In bold, the ones from the bathypelagic, and in regular type, those recovered from the photic samples. Numbers between brackets indicate the number of genera that represent those OTUs plus the unclassified at the genus level. (b) Venn diagram indicating the percentages of the sequences shared between photic and bathypelagic samples from neighbouring stations. Numbers inside brackets indicate the number of shared OTUs corresponding to that percentage of sequences. (c) Venn diagram indicating the percentages of the sequences shared between photic, OMZ and bathypelagic layers. Numbers inside brackets indicate the number of shared OTUs corresponding to that percentage of sequences. Indicated numbers in all Venn diagrams are extracted from the rarefied OTU-abundance tables. 
bioRxiv preprint doi: https://doi.org/10.1101/774992; this version posted September 19, 2019. The copyright holder for this preprint (which was not certified by peer review) is the author/funder, who has granted bioRxiv a license to display the preprint in perpetuity. It is made available under aCC-BY-NC-ND 4.0 International license.

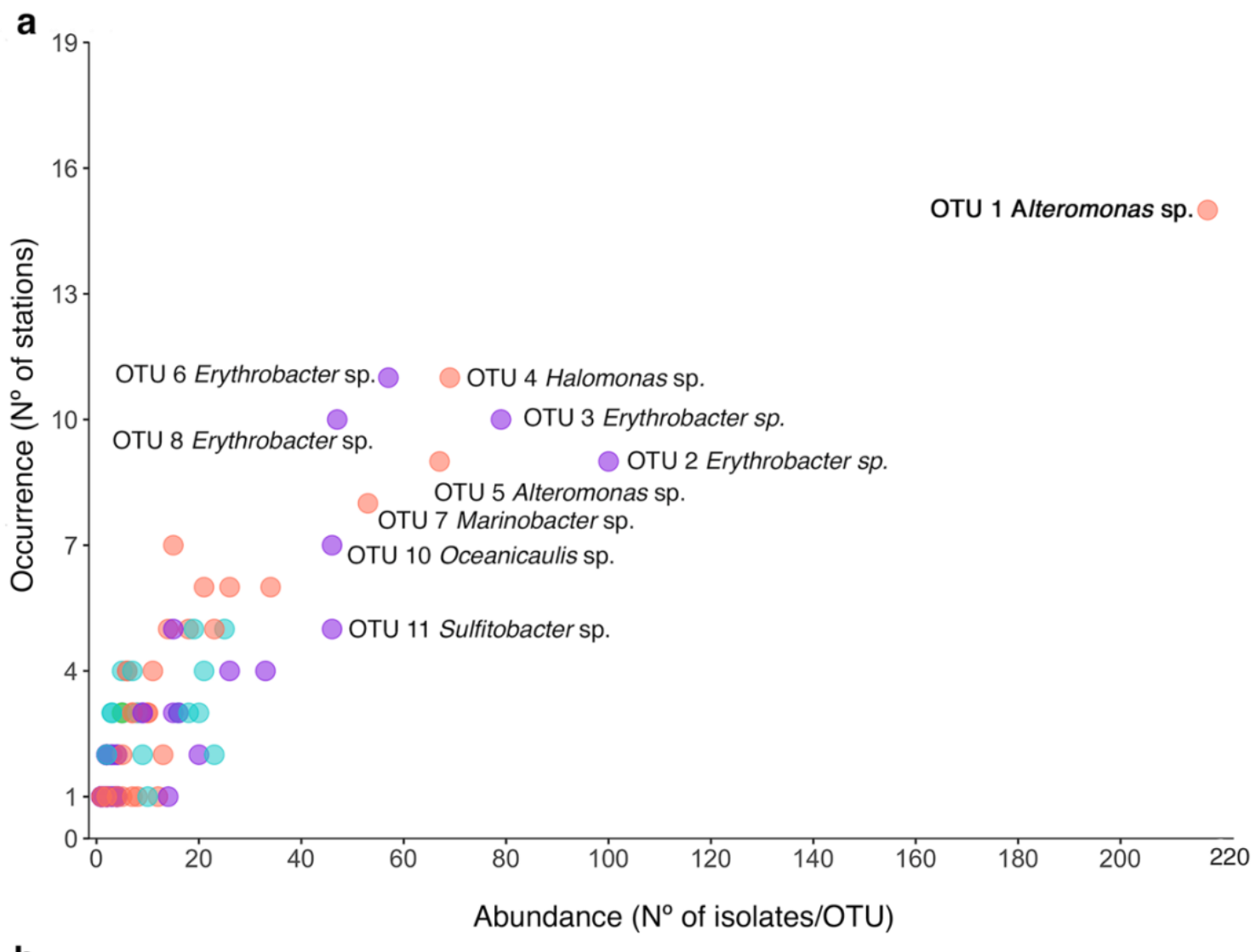

Phyllum or Class:

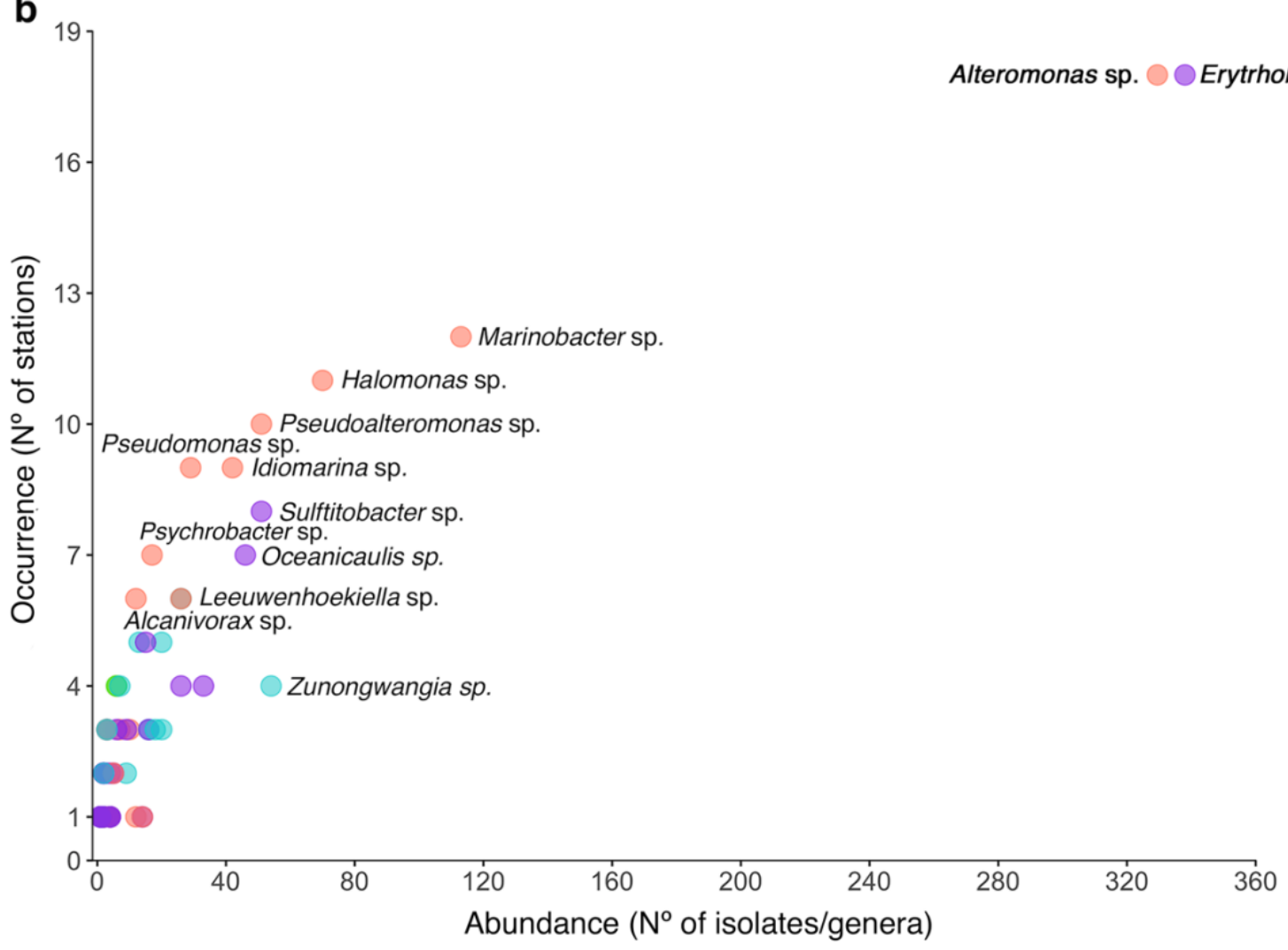

Gammaproteobacteria

- Alphaproteobacteria

Bacteroidetes

Firmicutes

Actinobacteria

Fig. 4 Abundance of the isolates retrieved versus their occurrence in the different stations of the study based on: (a) OTUs defined at 99\% similarity, (b) Genera retrieved in the total culture collection. In bold are indicated the most abundant and cosmopolitan OTUs or genera, and in regular type those with a regional distribution. The colour of the dots indicates the taxonomic (phylum or class) affiliation of the OTUs. 

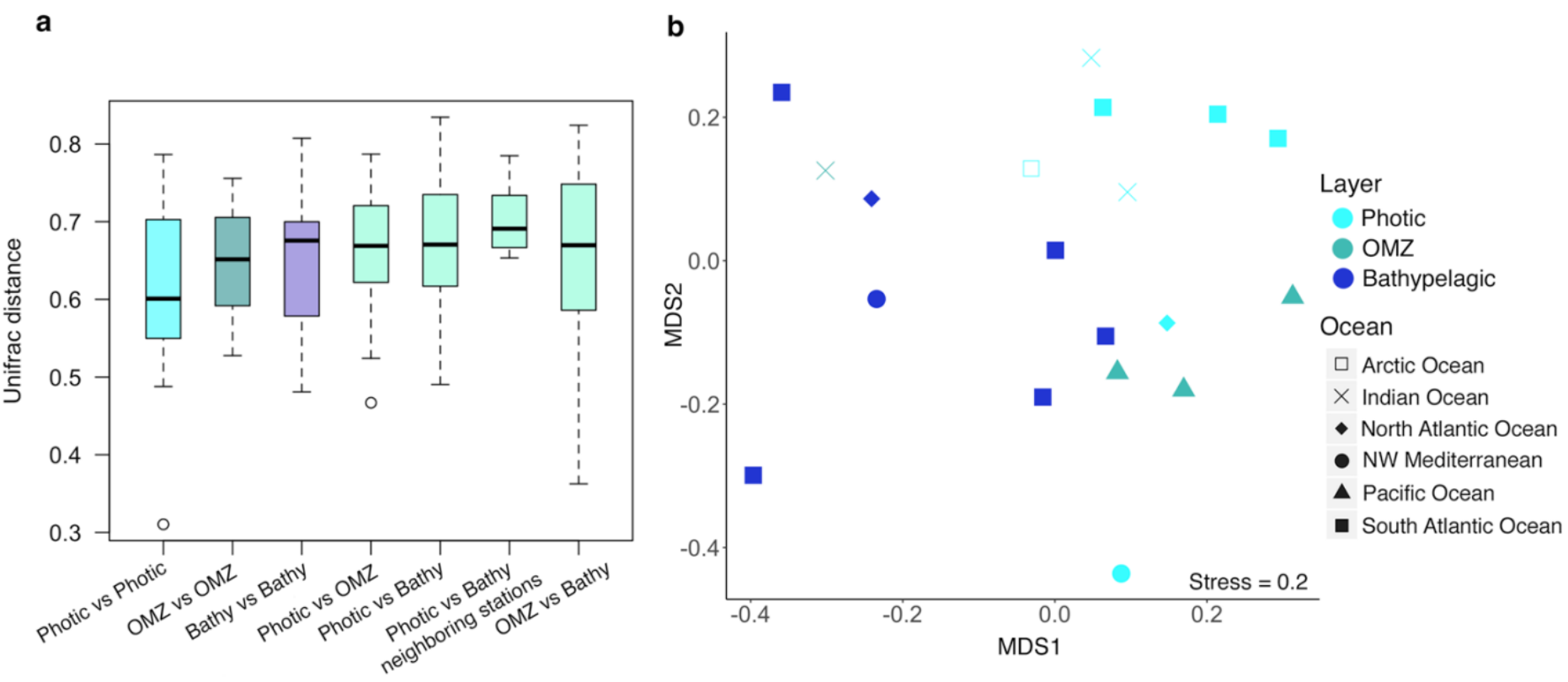

Fig. 5 Unweighted UniFrac distances between samples. (a) Boxplots showing the distribution of the UniFrac distances between photic-layer, oxygen minimum zone (OMZ), and bathypelagic (Bathy) samples. Same location stands for those photic-layer and bathypelagic stations belonging to neighbouring stations, even though samples were taken in different oceanographic cruises. ANOVA between values of the different groups were not statistically significant (P-value $=0.08)$. (b) Non-metric multidimensional scaling plot indicating the unweighted UniFrac distances between stations. Colour indicates the layer where the stations comes from: light-blue, Photic-layer; turquoise, Oxygen minimum zone (OMZ); and dark blue, Bathypelagic ocean. Shape indicates the oceanographic regions where the station comes from: empty square, Arctic Ocean; cross: Indian Ocean; filled diamond, North Atlantic; filled circle, North Western Mediterranean; filled triangle, Pacific Ocean; and filled square, South Atlantic Ocean. 

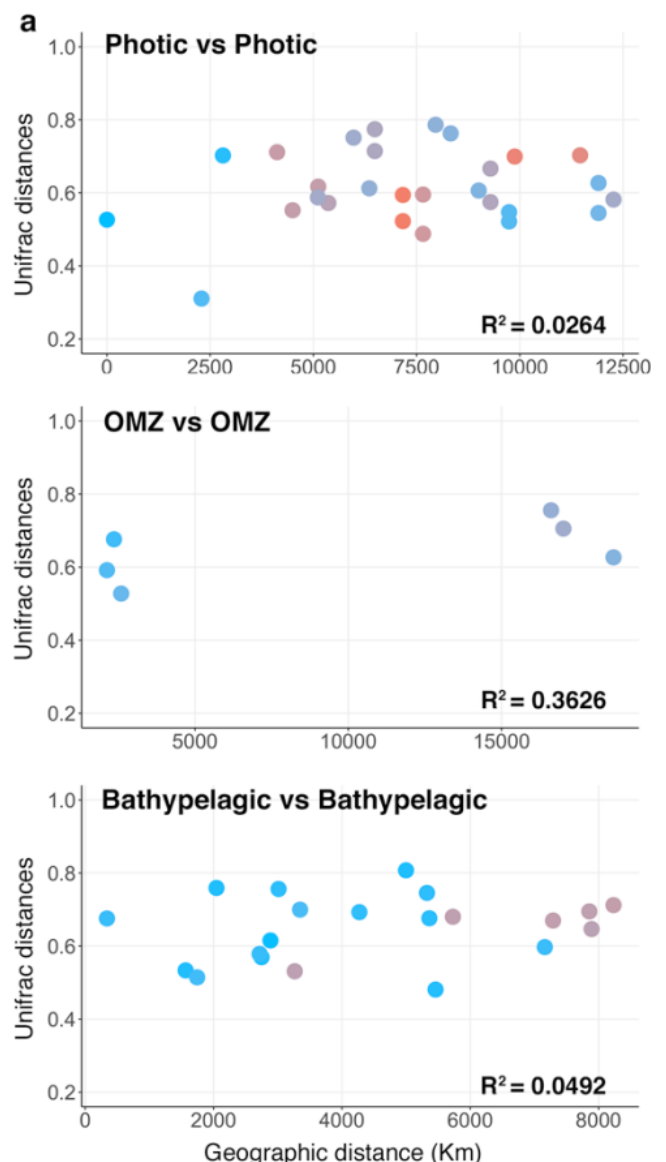

Differences in Temperature $\left(\mathrm{C}^{\circ}\right)$
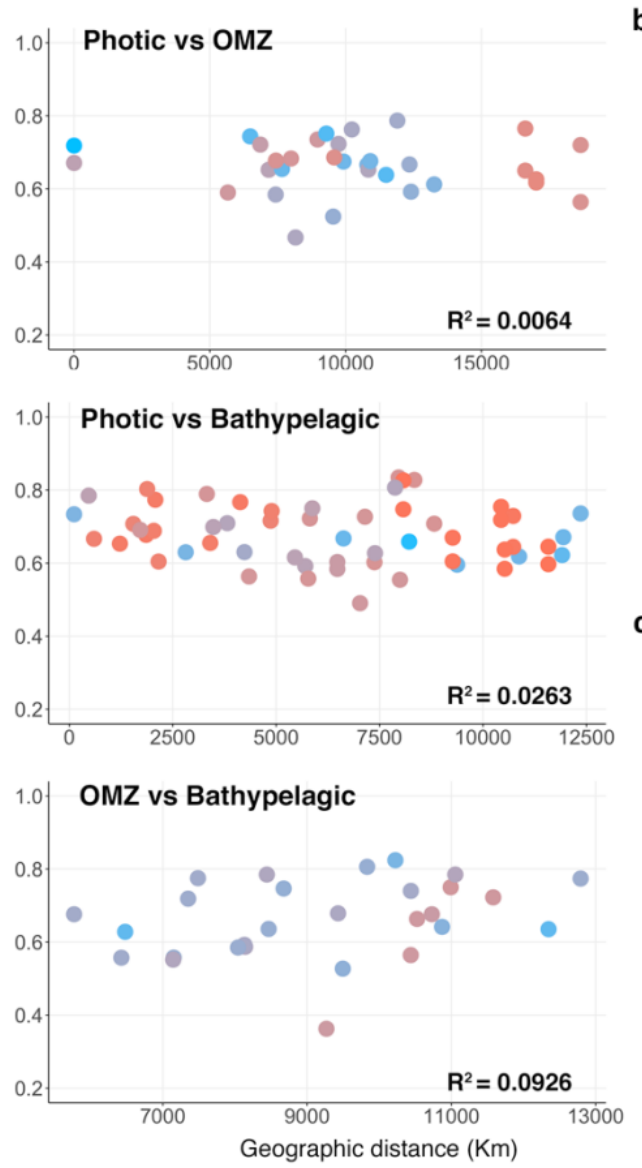

Geographic distance (Km) b

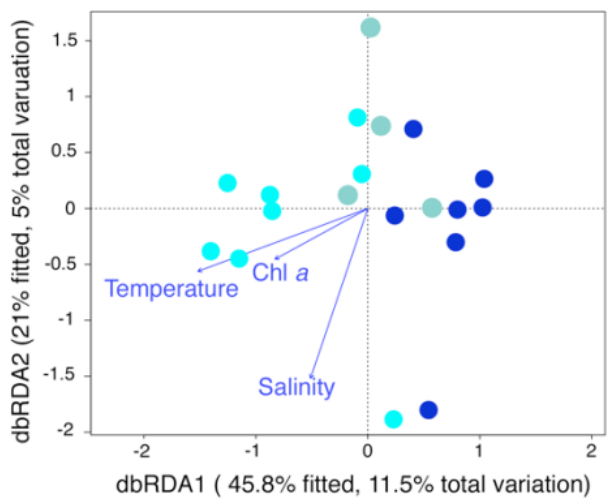

Layer: Photic OMZ Bathypelagic

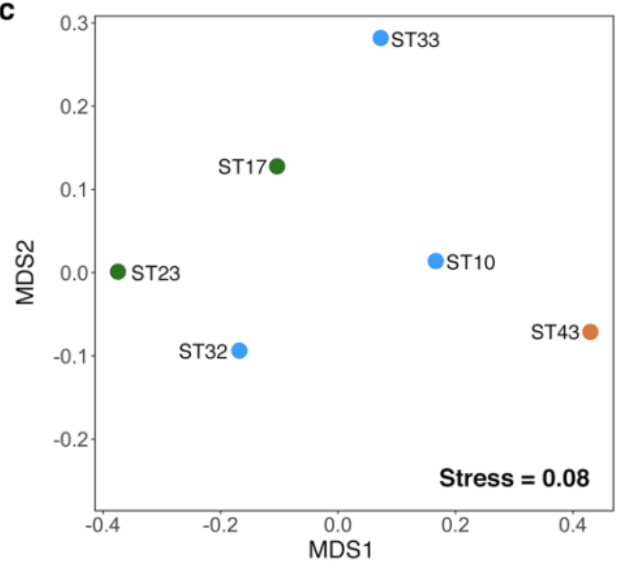

Water mass: $O$ NADW $O A A B W$ ONADW-CDW-AABW

Fig. 6 Correlation between UniFrac distances and environmental parameters. (a) Graphic representation of the genetic UniFrac comparisons between isolates retrieved from different layers. The color of the points represents differences in the in situ temperature between pair of samples. Blue colors indicate less than $10 \stackrel{\circ}{\mathrm{C}}$ of difference while orange colors indicate up to $25^{\circ} \mathrm{C}$ of difference. R-square values are indicated for each of the graphs. (b) Distance-based redundancy analysis of the samples (dots) with three possible explanatory variables (arrows) influencing the genetic distances between isolates of different samples (PERMANOVA $p>0.05$; temperature, salinity, and Chlorophyll a ( $\mathrm{Chl} \mathrm{a)} \mathrm{concentration).} \mathrm{The} \mathrm{ordination} \mathrm{was} \mathrm{done} \mathrm{on} \mathrm{the} \mathrm{UniFrac} \mathrm{distance}$ matrix. Samples are colored by layer: light-blue, Photic-layer; turquoise, Oxygen minimum zone (OMZ); and dark blue, Bathypelagic ocean. (c) Non-metric multidimensional scaling plot indicating the unweighted UniFrac distances between only bathypelagic stations. Stress is indicated inside the plot. Colour indicates the predominant bathypelagic water masses of the corresponding stations: NADW, North Atlantic deep water; AABW, Antarctic bottom water, and NADW-CDW-AABW, mix between North Atlantic deep water, Circumpolar deep water and Antarctic bottom water. 

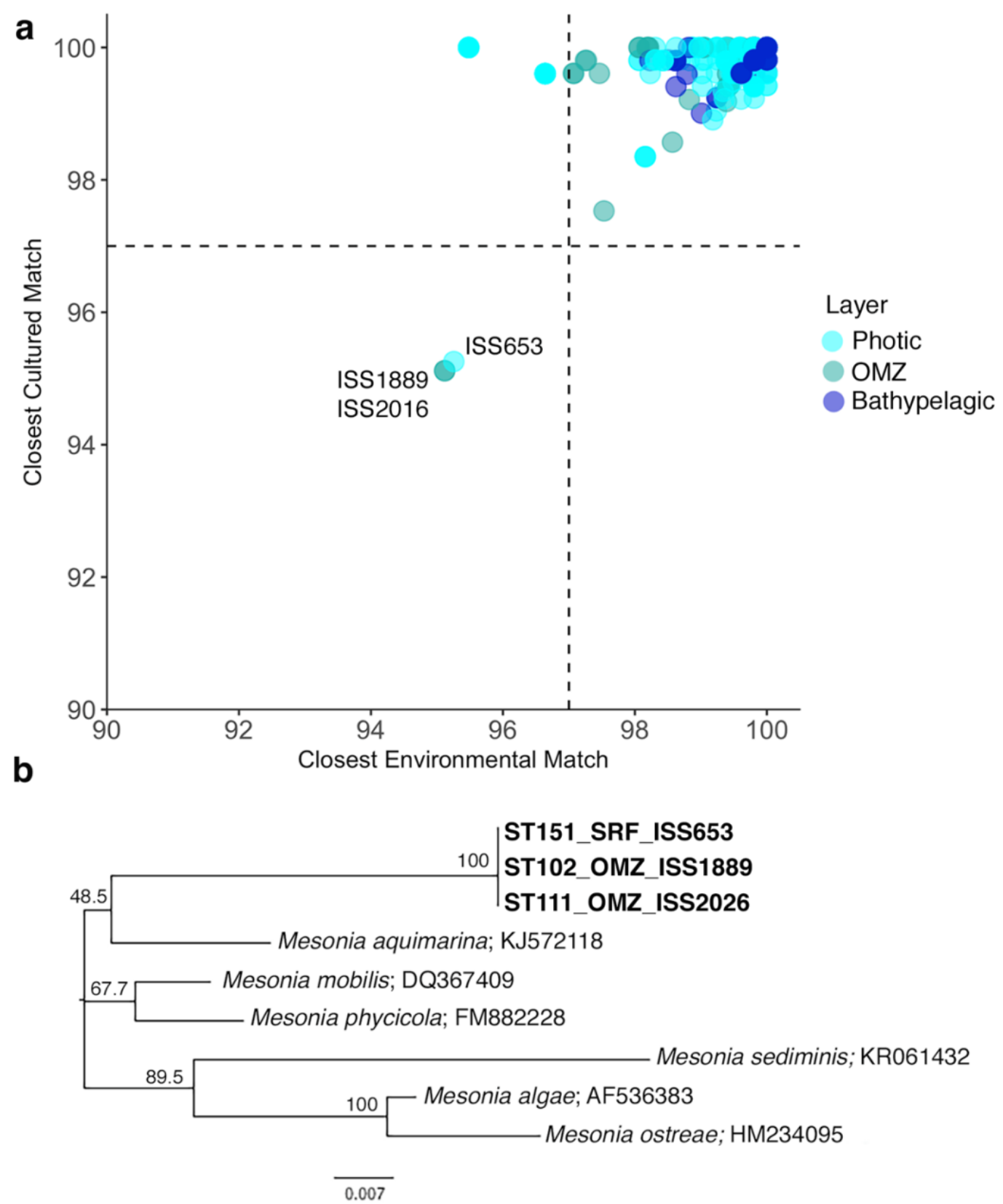

Fig. 7 Potentially novel isolates. (a) Percentages of similarity between the Closest Cultured Match (CCM) and the Closest Environmental Match of the 16S rRNA gene sequences. Horizontal and vertical lines represent the typical cut-off value of $97 \%$ and $99 \%$ commonly used for "species" delineation. Colour of the points indicate the layer where the isolates were retrieved from. (b) Neighbour Joining tree of the putative Mesonia isolates. The numbers in the nodes represent bootstrap percentages $>45 \%$, calculated from 1000 replicates. Putative new isolates are written in bold letters. SRF, surface isolates; OMZ, oxygen minimum zone. 